

IZA DP No. 3120

\title{
An Economic Analysis of Identity and Career Choice
}

Maria Knoth Humlum

Kristin J. Kleinjans

Helena Skyt Nielsen

October 2007 


\title{
An Economic Analysis of Identity and Career Choice
}

\author{
Maria Knoth Humlum \\ University of Aarhus \\ Kristin J. Kleinjans \\ University of Aarhus \\ Helena Skyt Nielsen \\ University of Aarhus \\ and IZA
}
Discussion Paper No. 3120
October 2007

\author{
IZA \\ P.O. Box 7240 \\ 53072 Bonn \\ Germany \\ Phone: +49-228-3894-0 \\ Fax: +49-228-3894-180 \\ E-mail: iza@iza.org
}

\begin{abstract}
Any opinions expressed here are those of the author(s) and not those of the institute. Research disseminated by IZA may include views on policy, but the institute itself takes no institutional policy positions.

The Institute for the Study of Labor (IZA) in Bonn is a local and virtual international research center and a place of communication between science, politics and business. IZA is an independent nonprofit company supported by Deutsche Post World Net. The center is associated with the University of Bonn and offers a stimulating research environment through its research networks, research support, and visitors and doctoral programs. IZA engages in (i) original and internationally competitive research in all fields of labor economics, (ii) development of policy concepts, and (iii) dissemination of research results and concepts to the interested public.
\end{abstract}

IZA Discussion Papers often represent preliminary work and are circulated to encourage discussion. Citation of such a paper should account for its provisional character. A revised version may be available directly from the author. 
IZA Discussion Paper No. 3120

October 2007

\section{ABSTRACT}

\section{An Economic Analysis of Identity and Career Choice}

Standard economic models which focus on pecuniary payoffs cannot explain why there are highly able individuals who choose careers with low pecuniary returns. Therefore, financial incentives are unlikely to be effective in influencing career choices of these individuals. Based on Akerlof and Kranton (2000), we consider a model of career choice and identity where individuals derive non-pecuniary identity payoffs. Using factor analysis on a range of attitude questions, we find two factors related to identity (career orientation and social orientation), which are important for educational choices. The implication is that policymakers and institutions of higher education need to focus on identity related issues rather than just improved financial incentives if they aim at attracting the high ability youth to occupations with excess demand for labor.

JEL Classification: $\quad 121$

Keywords: career choice, choice of higher education, identity, self-image

Corresponding author:

Helena Skyt Nielsen

Department of Economics

University of Aarhus

Bartholins Allé 4, Bld. 322

DK-8000 Aarhus C

Denmark

E-mail: HNielsen@econ.au.dk 


\section{Introduction}

Classic economic models which focus on pecuniary payoffs cannot explain why there are highly able individuals who choose low paid careers. Therefore, educational policy improving pecuniary incentives (e.g. financial bonuses) is likely to be ineffective in influencing the career choices of these individuals. To arrive at alternative policy suggestions, we follow the suggestions for research on economics of education as outlined by Akerlof and Kranton (2002). We integrate the sociological concept of identity into an economic model of career choice, and present empirical evidence that identity issues are as important for career choices as ability variables. As a consequence, educational policy and school reforms should not only focus on pecuniary incentives but also non-pecuniary incentives related to identity formation.

More specifically, we investigate whether non-pecuniary factors in terms of identity payoffs affect the choice of level and field of higher education. The idea is that there is a nonpecuniary reward from career choice through its influence on a person's identity (self-image). As in the fields of sociology and psychology, individuals are thought to think of themselves and others in terms of social categories. In addition to the standard pecuniary payoff, the utility function incorporates a non-pecuniary payoff associated with a person's identity, which depends on the agent's choice of social category and on how well the agent's characteristics and actions correspond to the ideal of that social category.

For the empirical analyses, we use the Danish part of the Programme for International Student Assessment (PISA) 2000, which is coupled with detailed register data and a follow-up survey. The follow-up survey includes questions about plans for future education. We use the answers to these questions to derive two measures of educational plans: one for the planned level and one for the planned field of education. The cohort of youths is also asked about their attitudes towards education, working life, and social issues. We use factor analysis to derive two orthogonal factors capturing an individual's identity: one factor which we label 'Career orientation' and one factor which we label 'Social orientation'. We refer to these as the 'career' and the 'social' factor, respectively. The career factor loads heavily on variables reflecting that career constitutes an important part of life and that chances for promotion are crucial for career choice. The social factor loads heavily on variables reflecting a social and cooperative attitude to education and life in general; i.e. questions reflecting the importance of helping other people and the responsibilities of society in solving social problems. The fact that the factors load heavily on questions related to general attitudes about career and society convinces us that the factors are closely related to a person's social identity in the work life.

We estimate logit and multinomial logit models to find the effect of the career and social factors on educational plans controlling for other observables, in particular for family background and ability. In line with Akerlof and Kranton (2002), we interpret a potential effect of the two factors as evidence for non-pecuniary identity-related returns. We find that for women, a higher career factor increases the level of education, whereas a higher social factor decreases it. There are no effects for men's behavior. When it comes to field of education, we find that a one standard deviation increase in the career factor moves $7 \%$ of the youth from Education and humanities to primarily Business, law and social sciences, whereas a one standard deviation increase in the social factor moves $9 \%$ of the youth away from Business, 
law and social sciences and into other fields (mainly Health sciences). Quantification of these effects in terms of monetary value shows that a one standard deviation increase in the career factor decreases the latent utility of choosing Education and humanities educations relative to Business, law and social science educations by the same amount as a decrease in relative annual wage income of US $\$ 4,751$. Similarly, a one standard deviation increase in the social factor is estimated to increase the latent utility of choosing Health science educations relative to Business, law and social science educations by the same amount as an increase in relative annual wage income of US $\$ 5,052$.

Thus, we find that there are clear economically significant effects of identity on educational choices. Furthermore, there exist important gender differences in how identity affects these choices, both in terms of the direction and the size of the effects. These findings can better explain the observed heterogeneity in occupational choices than standard economic models, including some of the observed gender differences. It also illustrates the benefits of incorporating sociological and psychological concepts into economics for improving the explanatory power of economic models.

The implication of our findings is that educational policy and school reforms should not only focus on improved financial incentives but also on identity related issues. In practice, this may involve marketing campaigns informing the youths about 'who fits in' a given institution of higher education or a given career path. This would allow the youth to make informed choices on which career choices are consistent with their self-images. It may also involve rethinking the curriculum or the didactics in order to attract the type of students that educators want to, or rethinking the educational institutions in terms of adding social activities directed at the type of students that educators want to attract. In the US, these considerations are mainly relevant for educational institutions, whereas in many European countries the student enrollment capacity is determined by governmental educational policy, and in this case these considerations are also relevant for policy makers. For instance, if policy makers aim at attracting more highly able individuals to careers leading to occupations with excess demand for labor (say, engineers), they may consider supporting information campaigns rather than introducing financial incentives in terms of additional government grants (for, say, engineering students).

The remainder of the paper is structured as follows: In section 2, we present economic and sociological arguments for the existence of non-pecuniary benefits of education. In section 3 , we present our conceptual framework of identity and career choice, integrating the classical economic model with the sociological view. In section 4, we describe the empirical framework for our estimation. Section 5 follows with a description of the data, and results are presented in section 6. Section 7 concludes.

\section{The Role of Non-Pecuniary Factors for Career Choice}

Initiated by the human capital revolution in the sixties (e.g. Becker, 1964; Schultz, 1963), economists have estimated the internal rate of return to education and investigated the extent of pecuniary motives for investments in education. Although this framework incorporates an important determinant of educational choices, it leaves many questions unanswered, such 
as why individuals choose apparently difficult and costly educations with low returns. One possibility is the existence of non-pecuniary benefits of education, whose importance for educational decision making has received increased recognition in economics during the last years (Arcidiacono, 2004; Cunha and Heckman, 2007).

The importance of non-pecuniary benefits to education is supported by empirical studies (for a survey of the literature, see Wolfe and Haveman, 2003). The focus of these studies has been on the effect of schooling on outcomes such as health, marriage, fertility, charitable giving, crime, asset management, consumption, children's schooling and children's health.

Education is also known to have additional, less specific non-pecuniary benefits resulting from tastes or preferences for education. Economists have modeled this by considering education not only as an investment but also as a consumption good. As such, education adds to the stock of human capital and is rented in the labor market, but it also enters the utility function directly as a consumption good (Heckman, 1976; Lazear, 1977; Schaafsma, 1976; Kodde and Ritzen, 1984).

Empirical studies have found some support for the existence of these types of nonpecuniary benefits. For example, Arcidiacono (2004) investigates benefits from preferences for a specific subject matter. He finds that the sorting of students by ability into different majors is explained by differences in preferences for majors rather than in pecuniary returns to ability. Gullason (1989) uses time series data on college enrollment to identify the consumption value of education. He focuses on one specific aspect of consumption value, namely the added value of education arising from avoiding the military draft during the Vietnam War. He finds a significant effect of this draft on college enrollment. Conversely, using the same measure of consumption value, Quinn and Price (1998) do not find evidence of non-pecuniary motives behind the choice of going to Medical School. Pratt, Hiller and Mace (1999) analyze educational choices of mature part-time students in the UK and find that $87 \%$ of these students choose their study to achieve 'personal satisfaction', whereas $67 \%$ want to gain 'a theoretical perspective'. Duncan (1976) estimates the total return to education by adding both pecuniary and non-pecuniary returns by use of canonical correlations. As measures of non-pecuniary payoffs he uses safe and healthy working conditions, control over time, employment and income stability. He finds an increased importance of education when non-pecuniary payoffs are added, and this effect persists when controlling for cognitive ability and in all specifications no matter which measure of non-pecuniary benefits is used.

Our approach is based on the model on economics and identity by Akerlof and Kranton (2000; with applications in 2002 and 2005), who integrate the notion of identity used in psychology and sociology into economic models by incorporating it in the utility function. The idea is that social identity can explain behavioral variation within a population with identical expected economic payoffs. In social identity theory, individuals knowingly belong to social categories. These social categories are associated with prescribed (or "ideal") characteristics and behavior, and individuals see themselves as belonging to a specific category and are by others considered to be in that category. If individuals deviate from the ideals of their category, they suffer what economists would call disutility. Thus, they have an intrinsic motivation to behave such that the social category (and, therefore, the self) receives a positive evaluation. 
For an overview of social identity theory, see Hogg, Terry, and White (1995) and Stets and Burke (2000).

In their study of schooling and identity, Akerlof and Kranton (2002) apply their general model to the simultaneous choice of social category and effort invested in schooling. In this framework, high school students choose one of three mutually exclusive social categories ( 'Leading Crowd', 'Nerds' and 'Burnouts') each of which yield different identity payoffs. The students derive utility from pecuniary returns to their effort (through human capital development) and a non-pecuniary identity payoff from belonging to a social category. The pecuniary payoff depends on inherent ability and effort net of its cost. The identity payoff depends on the social category as well as on the distance of the student's own characteristics and behavior from the ideals of that social category. The students maximize their utility by choosing the optimal combination of effort and social category. The choice of the social category involves the trade-off between the identity payoff from a social category and 'fitting in' the social category in terms of prescribed behavior and characteristics of a given social category.

This model can explain why economists often find a rather weak relationship between school resources and student outcomes. Furthermore, the incorporation of identity payoffs in the student's utility function gives new policy instruments based on social variables. The authors suggest that schools as institutions can (and should) try to influence students' optimal effort by influencing the defined social categories and the prescriptions of behaviors associated with them.

Thinking about identity in the framework of Akerlof and Kranton is also consistent with the theory that individuals invest in identity (Bénabou and Tirole, 2006). Here, individuals' investment can be welfare enhancing when undertaken for functional reasons (such as self-discipline), but can reduce welfare if related to affective reasons (such as self-esteem). For example, the increased study effort of 'nerds' can be seen as identity investment, and is likely to be welfare enhancing, but the decreased study effort of 'burnouts' is likely to reduce welfare, at least in the long term.

Empirical studies have found that social categories can influence performance: priming a social category can elicit stereotype-conform behavior (see, e.g., Hoff and Pandey, 2006). Even very subtle priming has been found to affect performance on tests - for example, women tend to score lower on math tests when their gender identity was made salient through questions asked before the test or even through subconscious gender identity cues (Steele and Ambady, 2007). A recent study has found additional effects of salient social identities on time and risk preferences (Benjamin et al., 2007) for individuals of different race and gender.

There also exists empirical evidence that identity matters for occupational choice. Dolton, Makepeace and van der Klaauw (1989) find that occupational choice is influenced by the relative social status attached to an occupation, and that this can explain why individuals choose occupations in teaching and public administration despite lower earnings. Related studies of professional identity in specific professions find evidence for the importance of non-pecuniary factors for occupational choice. For example, a general medical practitioner's decision of in which practice to work is dominated by non-pecuniary factors (Scott, 2002). Spetz (2002) finds that a large number of registered nurses undertake a baccalaureate degree in 
nursing for non-wage related career objectives and because of personal circumstances although an associate degree would be a much better financial investment in terms of lifetime earnings.

\section{A Model of Identity and Career Choice}

As a conceptual framework for understanding why and how non-pecuniary benefits might matter for educational choice, we consider a model that integrates the classic economic theory of education with the sociological and psychological theories where the student's identity or self-image - is salient. This section is based on the work of Akerlof and Kranton (2000) who propose a utility function that incorporates identity as an integrated factor in individual decision making. In Akerlof and Kranton (2002), this framework is extended to the field of economics of education, and the authors argue that many observed behavioral patterns in education can be explained by the incorporation of identity payoffs.

The model implies that identity can have explanatory power for educational choice above and beyond standard economic factors. In section 6 , we present support for this hypothesis based on the results from empirical analyses using a combined survey and register data set from Denmark.

\subsection{General Framework}

In standard economic models, an individual $i$ 's utility is assumed to depend on the actions of individual $i$, and potentially those of other individuals. Incorporating identity into the utility function, Akerlof and Kranton (2000) propose the following general utility function for individual $i$,

$$
U_{i}=U_{i}\left(a_{i}, a_{-i}, I_{i}\right)
$$

where $a_{i}$ is the actions of individual $i, a_{-i}$ is the actions of all other individuals, and $I_{i}$ is the self-image of individual $i$. The self-image, or equivalently, the identity, of individual

$i$ is assumed to be formed based on the individual's adherence to social categories. The basic idea is that incorporating the self-image of individuals into the utility function can help explain many observed choice patterns that the standard economic model cannot explain. The proposed representation of the self-image is

$$
I_{i}=I_{i}\left(a_{i}, a_{-i} ; c_{i}, \epsilon_{i}, \mathbf{P}\right)
$$

implying that the self-image is a function of individual $i$ 's own actions, and the actions of all other people. The self-image also depends on individual $i$ 's assignment to social categories, $c_{i}$, his (exogenous) characteristics, $\epsilon_{i}$, and prescriptions for the different social categories, $\mathbf{P}$. Prescriptions for a social category dictate the ideal characteristics and the ideal behavior for that social category. The prescriptions are central in understanding why the incorporation of identity payoffs can change predictions about choice behavior. An individual will prefer actions that are similar to the actions prescribed for his social category, ceteris paribus. According to this general framework, a rational economic agent will maximize utility, taking into account 
that his actions affect utility not only through their direct effect on utility, but also indirectly through their effect on his self-image.

\subsection{Utility, Identity and Career Choice}

Based on the above general framework of utility and identity, we set up a model of identity and career choice. ${ }^{1}$ In our model, the career choice is considered to be equivalent to the choice of higher education. For now, let the career choice of individual $i$ be given by the variable $e_{i}$, which is the effort put into educational attainment. Disregarding the dependence of utility on identity, a standard utility function depends only on income and effort. An individual chooses a career by maximizing utility, taking into account that the career choice affects future income, and that this career choice can be associated with pecuniary costs. ${ }^{2}$

When the utility function is assumed to be of the form (1), individual $i$ takes into account that the choice of $e_{i}$ affects his self-image, $I_{i}$. In this case, we can write the utility function as

$$
U_{i}=U_{i}\left(w\left(e_{i}, \epsilon_{i}\right), e_{i}, I_{i}\left(e_{i} ; c_{i}, \epsilon_{i}, \mathbf{P}\right)\right)
$$

where $w\left(e_{i}, \epsilon_{i}\right)$ is the income of individual $i$ given career choice $e_{i}$ and characteristics $\epsilon_{i}$. Thus, income and identity both depend on the behavior and the characteristics of individual $i$.

In the context of career choices, this form of utility function lends an explanation as to why some high-ability individuals choose e.g. relatively low-paying careers. Suppose that a high-ability individual belongs to a social category that for some reason prescribes that individuals should choose low-paying careers. This induces the high-ability individual to choose a lower amount of effort to put into educational attainment because the individual gets a higher self-image by exercising behavior close to the prescribed behavior of his or her social category. Thus, the observed career choice is not rational from the perspective of the traditional utility function. ${ }^{3}$

Note that the career choice, $e_{i}$, can easily be thought of as not necessarily just the extent of effort exerted (e.g. the level of education), but also as different types of effort (e.g. the field of education). Both level and field of education are likely to be part of the prescriptions for social categories, and thus individuals choose both level and field, recognizing how these choices in turn match the prescriptions of their social category.

The above model predicts that an individual's social category affects his or her career choices. The standard utility function approach predicts that an individual's social category has no effect on his career choices.

\footnotetext{
${ }^{1}$ Akerlof and Kranton (2002) argue that identity payoffs are likely to be important in educational decisionmaking. Although our focus is slightly different from theirs, we consider it a natural extension that identity payoffs should matter for career choices.

${ }^{2}$ This is a simplification of the general framework above where utility was assumed to depend on other people's actions as well.

${ }^{3}$ Akerlof and Kranton (2002) give an example where utility functions are conditional on social categories and show that under specific assumptions some high-ability individuals will exert lower effort than economically optimal.
} 


\subsection{Social Categories}

A central question in this framework is whether social categories are assigned or chosen. Consistent with the former, in our empirical analysis we assume that social categories are exogenous. This does not preclude, however, that the category is the result of "continuous" choices made and impressions received since early childhood. In this sense, social categories can then be considered chosen and exogenously given at the same time.

Some social categories are mutually exclusive by construction, such as gender categories, except under relatively rare circumstances. Other social categories need not necessarily be. For example, it is perfectly possible to have both an at-work identity and an at-home identity. According to Hogg, Terry and White (1995), in social identity theory each individual belongs to a set of social categories. How important the membership of each social category is to the individual's self-image varies across individuals and social categories. Thus, we can think of an individual's assignment to social categories as placing the individual at some point in a social category space that for each dimension (social category) measures the importance of the social category for the self-image.

\section{Empirical Framework}

As Akerlof and Kranton (2002) note, it may be difficult to test the theoretical model directly because it is difficult to separately identify the effect of identity from that of tastes and from selection on observable and unobservable ability. However, assume that we can measure social identity (or social category) separately from ability and tastes. Then, if this measure of social identity is statistically important for the choice of education, it implies a rejection of the null hypothesis that identity does not matter for career choices. Our empirical strategy is to construct measures of social identity that are as clear as possible separated from ability and tastes for a specific education, and then to investigate whether those measures are correlated with the choice of education. If that is the case, we take it as support for the identity approach rather than the purely economic model, and the pattern of correlation tells us which kinds of educational choices are prescribed behavior for certain social categories.

We conduct logit and multinomial logit regressions to investigate the effect of social identity on the choice of the level and field of college education. To classify individuals into social categories, we use factor analysis. The variables that should enter the factor analysis are those that could indicate ideal attitudes of people in a given social category. Since the factors should not reflect ability or tastes for a certain level or field of education, only variables reflecting attitudes that are not taste or ability related should be used. In the empirical analysis, we assume that the factors are exogenous with respect to choice of level and field of education.

We identify two underlying factors which we interpret as social categories: a career factor and a social factor. We predict factor scores for each individual which indicate the extent to which the person is career oriented and socially oriented, respectively, and include those as explanatory variables in the regressions. If the factors vary systematically with the investments in level and field of education, we interpret this as suggestive evidence that 
identity payoffs are an important part of educational decision making. Thus, this would suggest that an exclusive focus on pecuniary benefits of educational choice will be misleading. This conclusion is only valid, however, if the factors do not reflect characteristics that are remunerated in the pecuniary component of the utility function or tastes for level or field of education. This is an untestable assumption.

The set of explanatory variables used in the empirical analyses includes ability measures in order to account for the influence of ability on pecuniary returns. In addition, a number of other individual characteristics enter the equation as independent variables. Here, we include a variety of family characteristics, such as measures of parental socioeconomic status and information about birth order. These variables may be part of prescribed characteristics, or they may influence choice of education because they reflect, for instance, ability or tastes for education.

The described empirical approach includes two continuous factor scores as explanatory variables, assuming that these factors describe aspects of an individual's social identity. As a robustness check, to mirror the assumption of mutually exclusive categories, we also divide the students into four mutually exclusive groups, which gives similar results. ${ }^{4}$

In order to quantify the effect of the factors, and thus of identity-related issues, we round off the analysis by estimations of conditional logit models which provide the dollar equivalent value of the factor scores. To obtain these monetary values, we include the counterfactual predicted annual wage incomes for each possible education plan as an additional explanatory variable in a conditional logit model, and then we compare the effect of the factor scores on the career choice to that of the predicted wage income.

\section{The Data}

The data set used in the empirical analyses is a combination of the Danish part of the international PISA 2000 survey (PISA), a follow-up survey in 2004 (PISA-FUS) ${ }^{5}$, and Danish register data (REG) on the PISA youth and their parents. The combined data set is labelled PISA-Longitudinal (PISA-L). ${ }^{6}$ This data set consists of individuals born in 1984 who were enrolled in an education in 2000, which was the criterion for participation in PISA in Denmark. $^{7}$

One of the advantages of this data set is the availability of a multiplicity of variables. We not only have access to the entire range of PISA variables, but also to the variables from FUS regarding individuals' attitudes and educational plans, in which we are particularly interested. Furthermore, the register data allow us to add very accurate and detailed information on parental background, e.g. parental education and income. The PISA data includes

\footnotetext{
${ }^{4}$ These groups are: (1) those who score high on the career factor and low on the social factor, (2) those who score high on the social factor and low on the career factor, (3) those who score high on both factors, and (4) those who score low on both factors. Including these four indicator variables in the regressions instead of the continuous factor scores gives similar results but shows that the relative importance of the factor is important, and not the absolute score (results not shown).

${ }^{5}$ The follow-up survey is entitled "Young people in job or education - values, choices and dreams for the future".

${ }^{6}$ See Jensen and Andersen (2006) for more information on PISA-L.

${ }^{7}$ The PISA data were collected using two-stage stratified cluster sampling, with schools as the primary sampling units. The complex sampling design is not taken into account in the empirical analyses.
} 
a large amount of variables; among them are a test score in reading, self-concepts of ability, information on the household and information on cross-curricular competencies. ${ }^{8}$

\subsection{Sample Selection}

The focus of this paper is the choice of higher education. Hence, for our empirical analyses we select a subsample from PISA which consists of 1,854 individuals who had completed or were currently enrolled in a high school education in 2004. We will refer to this sample as the high school sample. The result of the sample selection is a more homogenous sample than in the original PISA, both in terms of educational path and parental background. ${ }^{9}$ We use the high school sample for the factor analysis in section 6.1 since this will provide us with the clearest picture of the social categories that are relevant for this population.

For the empirical analyses of the choice of higher education, we restrict the sample to those individuals who in 2004 plan to enroll in a higher education. ${ }^{10}$ In addition, we exclude individuals with missing values for some of the explanatory variables used in the estimations (42 observations). The final sample consists of 892 individuals. We refer to this sample as the higher education sample.

Because of this sample selection, the individuals in our sample have higher abilities and come from more advantageous family backgrounds than the original PISA cohort. There are two reasons for this: First, the response rate in the 2004 follow-up survey in general was about $75 \%$, and only individuals who participated in this survey are included in our samples. The respondents to the follow-up survey tend to be more successful than the nonrespondents as measured, for example, by reading scores. Secondly, in the higher education sample attention is limited to the choice of the first higher education, where the 'choice' is given by the educational plans of each individual in 2004. Again, those who report educational plans have, on average, higher reading scores and come from a more advantageous family background than those who report having no educational plans. The final results should be interpreted keeping this sample selection process in mind.

\subsection{Explanatory Variables}

Table 1 shows descriptive statistics of the variables used in the empirical analyses for the higher education sample, and for the sample divided by gender. ${ }^{11}$ The majority of the sample (59\%) are women, and the average reading score is above the OECD average, although Denmark

\footnotetext{
${ }^{8}$ Detailed information on the variables and the questionnaires in PISA can be found in OECD (2002a). Information on the sampling design, construction of weights etc. is available in OECD (2002b), and the specific design for Denmark is described in AKF et al. (2001).

${ }^{9}$ The high school sample is also selective in the sense that it only includes individuals who participated both in the PISA survey in 2000 and in the follow-up survey in 2004. In addition, it only includes individuals who could be coupled with the register data.

${ }^{10}$ As a result, 920 individuals are dropped due to missing enrollment plans. Of these, 544 have no current plans, 51 do not know if they have current plans, and 325 plan to start a new education. Of the 325,103 do not know what education they plan to start, and 222 mention a specific education. Of the 222,12 are unclassifiable, 20 only enter the length of the planned education but no subject, and 190 enter an education of a lower level than higher education.

${ }^{11}$ Table 17 in the appendix gives a more detailed description of the variables. See OECD (2002a) for additional information on the construction of the indices from PISA.
} 
Table 1: Descriptive Statistics for the Higher Education Sample

\begin{tabular}{|c|c|c|c|c|c|c|}
\hline \multirow[b]{2}{*}{ Variable } & \multicolumn{2}{|c|}{ All } & \multicolumn{2}{|c|}{ Men } & \multicolumn{2}{|c|}{ Women } \\
\hline & Mean & St.d. & Mean & St.d. & Mean & St.d. \\
\hline Female & 0.590 & & & & & \\
\hline Abilities and self-concepts & & & & & & \\
\hline PISA reading score $(/ 100)$ & 5.530 & 0.756 & 5.515 & 0.765 & 5.541 & 0.750 \\
\hline Cooperative learning & 0.528 & 0.860 & 0.508 & 0.859 & 0.542 & 0.862 \\
\hline Self-concept in reading & 0.444 & 0.751 & 0.366 & 0.774 & 0.498 & 0.730 \\
\hline Academic self-concept & 0.779 & 0.884 & 0.949 & 0.854 & 0.661 & 0.886 \\
\hline Mathematical self-concept & 0.814 & 0.902 & 1.090 & 0.774 & 0.622 & 0.935 \\
\hline Family and parental background & & & & & & \\
\hline Only child & 0.061 & & 0.060 & & 0.061 & \\
\hline Oldest child & 0.367 & & 0.374 & & 0.361 & \\
\hline Nuclear family & 0.740 & & 0.760 & & 0.726 & \\
\hline Urban & 0.198 & & 0.257 & & 0.158 & \\
\hline Higher education - father & 0.371 & & 0.448 & & 0.317 & \\
\hline Vocational education - father & 0.397 & & 0.361 & & 0.422 & \\
\hline Higher education - mother & 0.418 & & 0.451 & & 0.395 & \\
\hline Vocational education - mother & 0.279 & & 0.270 & & 0.285 & \\
\hline Measure of parental income & 12.819 & 0.455 & 12.852 & 0.445 & 12.796 & 0.462 \\
\hline Family wealth (PISA) & 0.600 & 0.714 & 0.642 & 0.739 & 0.571 & 0.695 \\
\hline Missing parental education & 0.067 & & 0.071 & & 0.065 & \\
\hline Number of observations & & & 36 & & 5 & \\
\hline
\end{tabular}

scored relatively low on the reading test in 2000. ${ }^{12}$ This is a result of the highly selective sample since we only include students with plans for higher education. Women have on average higher reading scores than men. The reading score is used as one of several proxies for ability.

The PISA survey also asked questions about self-perceived abilities in different school subjects, from which three self-concept indices were derived and included in the PISA data set: self-concepts in reading, academics, and mathematics. Including these indices in the regressions makes it possible to control for individuals' own perceived abilities, which might be just as important as their actual abilities in determining educational choices. The selfperceived abilities may to some extent be regarded as controls for ability. Women have a higher self-concept in reading, while men have higher academic and mathematical self-concepts.

We include the PISA index for cooperative learning as a proxy for social skills. This index is constructed based on questions such as whether you like to work with other students and whether you like to help other people to do well in a group. Women tend to score higher than men on this index. There are also some other gender differences. Measured by parental education and income, men come from more advantageous family backgrounds than women. Men are also more likely to come from a nuclear family. This is not surprising as women outnumber men in higher education in Denmark.

In 2004, the time of the follow-up survey, $66 \%$ of the respondents were undertaking an education, $26 \%$ were working, and the remaining $8 \%$ were on sabbatical or unemployed. The majority of those undertaking an education were enrolled in high school educations.

\footnotetext{
${ }^{12}$ The original PISA reading score has a mean of 500 and a standard deviation of 100 across all the countries participating in PISA. Here, the original score is scaled by 0.01 .
} 


\subsubsection{Educational Plans}

The variables of educational choice are defined on the basis of answers to questions in the follow-up survey from 2004 about educational plans. The use of educational plans instead of actual educational choices is useful because plans give a better description of the demand for education than attained education. Furthermore, it is useful to have a measure of educational plans that implies that we (roughly) look at individuals at the same point in their lives because the adherence to certain social categories might change over the lifetime.

Individuals were asked to indicate their plans for future enrollment in education. As mentioned earlier, we limit our attention to the choices of high school graduates and individuals who are enrolled in a high school education at the time of the 2004 survey and who plan to take a higher education. For the few individuals who have already enrolled in a higher education (about 12\%) we use the information about their current educational enrollment if they have not indicated any plans for future enrollments into other higher educations. $^{13}$

The following two questions are used to derive the respondents' educational plans:

- Do you currently have plans to start a (new) education? (e.g. after completion of present education)

If this question is answered in the affirmative, a second question is asked about the level and field of education:

- Which education would you like to start? (your first priority)

The open-ended answer to the last question has been coded according to commonly used Danish educational codes. From this coding, individuals are divided into two categories for level of higher education: 'short- and medium-cycle educations' and 'long-cycle educations', and into four categories for the field of higher education: 'Education and humanities', 'Engineering and natural sciences', 'Business, law, and social sciences', and 'Health sciences'.

Table 2 shows the distribution of educational plans over level and field for the higher education sample. More than half of the sample (58\%) plans to start a long-cycle education, and about one fourth plans to take an education in the fields of 'Education and humanities' and 'Engineering and natural science'. Slightly more individuals are interested in 'Business, law, and social science', and slightly less in 'Health sciences'. Patterns of educational enrollment differ across gender. More men tend to enroll in long-cycle educations compared to women, and the majority enrolls in the fields of 'Engineering and natural sciences' and 'Business, law, and social sciences', whereas women tend to avoid 'Engineering and natural sciences'.

\section{Results}

This section starts with a description of the results from the factor analysis on the high school sample. As mentioned before, the aim of the factor analysis is to identify measures of social

\footnotetext{
${ }^{13}$ Individuals are asked to provide name, educational institution, and duration of their current higher education, if any.
} 
Table 2: Distribution of Educational Plans in Higher Education Sample

\begin{tabular}{|c|c|c|c|}
\hline Field/level & $\begin{array}{c}\text { Short-cycle and } \\
\text { medium-cycle higher } \\
\text { education (2-4 year } \\
\text { college) }\end{array}$ & $\begin{array}{c}\text { Long-cycle higher } \\
\text { education }(5+\text { year } \\
\text { college })\end{array}$ & Total \\
\hline \multicolumn{4}{|l|}{ All } \\
\hline Education and humanities & 15.1 & 10.7 & 25.8 \\
\hline Engineering and natural sciences & 6.8 & 18.6 & 25.4 \\
\hline Business, law, and social sciences & 8.4 & 21.1 & 29.5 \\
\hline Health sciences & 11.3 & 8.0 & 19.3 \\
\hline Total & 41.7 & 58.3 & 100.0 \\
\hline \multicolumn{4}{|l|}{ Men } \\
\hline Education and humanities & 8.5 & 8.7 & 17.2 \\
\hline Engineering and natural sciences & 10.9 & 31.7 & 42.6 \\
\hline Business, law, and social sciences & 10.1 & 22.4 & 32.5 \\
\hline Health sciences & 1.1 & 6.6 & 7.7 \\
\hline Total & 30.6 & 69.4 & 100.0 \\
\hline \multicolumn{4}{|l|}{ Women } \\
\hline Education and humanities & 19.8 & 12.0 & 31.7 \\
\hline Engineering and natural sciences & 4.0 & 9.5 & 13.5 \\
\hline Business, law, and social sciences & 7.2 & 20.2 & 27.4 \\
\hline Health sciences & 18.4 & 8.9 & 27.4 \\
\hline Total & 49.4 & 50.6 & 100.0 \\
\hline
\end{tabular}

identity to investigate the impact of these measures on educational choices. We then present the results from discrete choice analyses of both level and field of education.

\subsection{Factor Analysis}

Factor analysis is conducted on a subset of the questions in the 2004 follow-up survey regarding individuals' attitudes to identify potential social categories related to these attitudes. All of these questions have ordinal response scales, where respondents rank their level of agreement with given statements on a scale from 1 to 5 , where ' 1 ' is 'totally disagree', '2' is 'partly disagree', '3' is 'both/and', '4' is 'partly agree', and '5' is 'totally agree'. For answers equal to '8' (don't know) and '9' (missing), the answers are set equal to the median of the particular question to avoid a further reduction in the sample size. ${ }^{14}$ The total number of questions included in the factor analysis is 31 , and the factor analysis is performed on the standardized variables. Applying principal factor analysis and a varimax rotation of two factors yields two factors which are plausibly related to identity. ${ }^{15}$

Table 3 displays the factor loadings of the two factors. ${ }^{16}$ Each of the factors load heavily on important questions about attitudes towards education, working life, and society in general, which most likely are related to identity. In our interpretation, these two factors determine two social categories: a career oriented category and a socially oriented category.

\footnotetext{
${ }^{14}$ The percentage of observations replaced in this manner is small, it varies for each question between $0.0 \%$ and $3.2 \%$.

${ }^{15}$ An oblique factor analysis using a promax rotation yields similar results. The number of factors to rotate was determined by the number of eigenvalues greater than 1. A maximum likelihood factor analysis yields similar results, and tests for the number of factors suggest to retain two factors.

${ }^{16}$ The factor loadings for the social factor have been multiplied by -1 in order to ease interpretation.
} 
Table 3: Rotated Factor Loadings

\begin{tabular}{lc}
\hline \hline Question & Factor loading \\
\hline $\begin{array}{l}\text { Career factor } \\
\text { One of the most important things in your work life will be a good career }\end{array}$ & 0.542 \\
(climbing the ladder) & 0.489 \\
If you want the job of your dreams, you have to specialize. The sooner, & 0.409 \\
the better & 0.391 \\
Your job will give your life meaning & 0.325 \\
Without competition, society would grind to a halt & \\
When people run into problems, it is usually their own fault. They have & 0.311 \\
to deal with it themselves & 0.302 \\
Science and industry will solve our global environmental problems \\
$\begin{array}{l}\text { People who show initiative are not rewarded enough in today's society } \\
\text { Social factor }\end{array}$ \\
$\begin{array}{l}\text { The best way to achieve social security for ordinary people is to stand } \\
\text { together }\end{array}$ \\
$\begin{array}{l}\text { An education that develops your ability and desire to cooperate with other } \\
\text { people }\end{array}$ \\
$\begin{array}{l}\text { Society always shares the responsibility for solving people's problems } \\
\text { An education where you learn by doing }\end{array}$ \\
$\begin{array}{l}\text { The global environmental problems are so big now that technical solutions } \\
\text { alone are not enough. It takes a change of attitudes }\end{array}$ \\
$\begin{array}{l}\text { If a friend or someone in your family runs into serious problems, you will } \\
\text { be there for them - regardless of that person's actions }\end{array}$ \\
$\begin{array}{l}\text { You do not want to be locked into a specific type of job. You want to be } \\
\text { able to switch between different fields }\end{array}$ \\
$\begin{array}{l}\text { For you, family and spare time will always take priority; work will have to } \\
\text { fit in }\end{array}$ \\
$\begin{array}{l}\text { Notes: } \\
\text { 1) Questions where the absolute factor loading is less than 0.30 are not shown. }\end{array}$ \\
\hline \hline
\end{tabular}

The first factor is interpreted as career orientation as it loads heavily on questions regarding statements about the importance of career and work for a meaningful life. The second factor is interpreted as social orientation as it loads heavily on questions regarding statements about the importance of cooperation, social responsibility and social issues, such as other people's well-being. ${ }^{17}$

Factor scores are predicted for each individual, which are then used as explanatory variables in the educational choice models. For each question included in the factor analysis, table 15 in the appendix shows the weights used to predict the factor scores for the two factors.

Table 4 shows summary statistics for the factor scores for the whole sample and divided by gender. The gender difference in both factors is striking - women have on average a much lower career factor than men. The average career factor for women is slightly negative, while it is positive for men. For the social factor, the pattern is exactly the opposite and even more pronounced. As a robustness check, we have calculated factors based on the gender specific samples. The interpretation of the factors and the empirical analysis is robust to such a change.

\footnotetext{
${ }^{17}$ Our findings are consistent with the factors identified by Lackland and De Lisi (2001), who arrive at four factors of which only two ('humanitarian concerns' and 'utility value') are found to be related to field choice. Their factor 'humanitarian concerns' is very similar to our social factor, whereas the factor labeled 'utility value' is very similar to our career factor.
} 
Table 4: Factor Scores in Higher Education Sample

\begin{tabular}{l|rr|rr|rr}
\hline \hline & \multicolumn{2}{|c|}{ All } & \multicolumn{2}{c|}{ Men } & \multicolumn{2}{c}{ Women } \\
& Mean & S.d. & Mean & S.d. & Mean & S.d. \\
\hline Career factor & 0.085 & 0.796 & 0.236 & 0.787 & -0.020 & 0.787 \\
Social factor & -0.028 & 0.823 & -0.243 & 0.849 & 0.121 & 0.771 \\
\hline \hline
\end{tabular}

\subsubsection{Determinants of Factor Scores}

Our interpretation of the factors is based on the questions on which the factors load heavily. As support for this interpretation, we present the results of standard OLS regressions of the factors on background variables for the higher education sample in tables 5 and 6 . Specification 1) in each table shows the results from a regression of each of the factors on the set of explanatory variables that we later use in the regressions of educational choice. Additionally, specification 2) includes the indices from PISA that appeared to be most important in explaining the factors.

A couple of things are important to take away from these results. First, the significant gender differences in the factors found in the summary statistics persist in multivariate analysis. ${ }^{18}$ Secondly, the coefficient of the reading score is negative in all specifications, suggesting that an increase in the reading score is associated with a lower score on both factors. Third, an increase in the index of cooperative learning is positively related to the social factor but is not statistically significant for the career factor. Fourth, parental background is generally not closely related to the factor scores, although there is a positive association between family wealth and the career factor (coefficients not shown). Finally, the importance of the additional indices from PISA included in specification 2) supports our interpretation of the two factors as a career factor and a social factor. For example, indices for effort and perseverance, instrumental motivation and competitive learning all have positive coefficients in specification 2) for the career factor, and indices of cooperative learning and disciplinary climate are important for the social factor.

Specification 3) in tables 5 and 6 tests whether differences in preferences for employment in the public or private sector are driving the factor scores associated with the social factor. ${ }^{19}$ Since the included variables are not statistically significant for the social factor this hypothesis is rejected. For the career factor, the coefficients on both indicator variables are negative, which further confirms our interpretation of this factor as a career factor.

To give an impression of how the factor scores vary across level and field of education, we show plots of the factor scores by level and field of education. There is a tendency for those who choose long-cycle educations to have higher scores on the career factor (Figure 1), while the opposite is the case for the social factor (Figure 2 ). Figure 3 shows the career factor score by field and gender. In general, individuals who choose 'Education and humanities' (Hum) educations have lower factor scores than those who choose 'Engineering and natural sciences' (Nat) and 'Business, law and social sciences' (Soc) educations. Figure 4 shows that, on

\footnotetext{
${ }^{18}$ By construction, the factors are $\mathrm{N}(0,1)$ in the high school sample. Therefore, the magnitude of the gender difference roughly compares to a $.22 * \mathrm{~s} . \mathrm{d}$. and a $.32 * \mathrm{~s}$.d. difference in means, respectively.

${ }^{19}$ These indicator variables were constructed based on a question from the follow-up survey where individuals are asked which job characteristic they find most important. Three options are given: (1) shorter / more convenient work hours, (2) challenges on the job, and (3) job security.
} 
Table 5: OLS Regressions of the Career Factor on Explanatory Variables

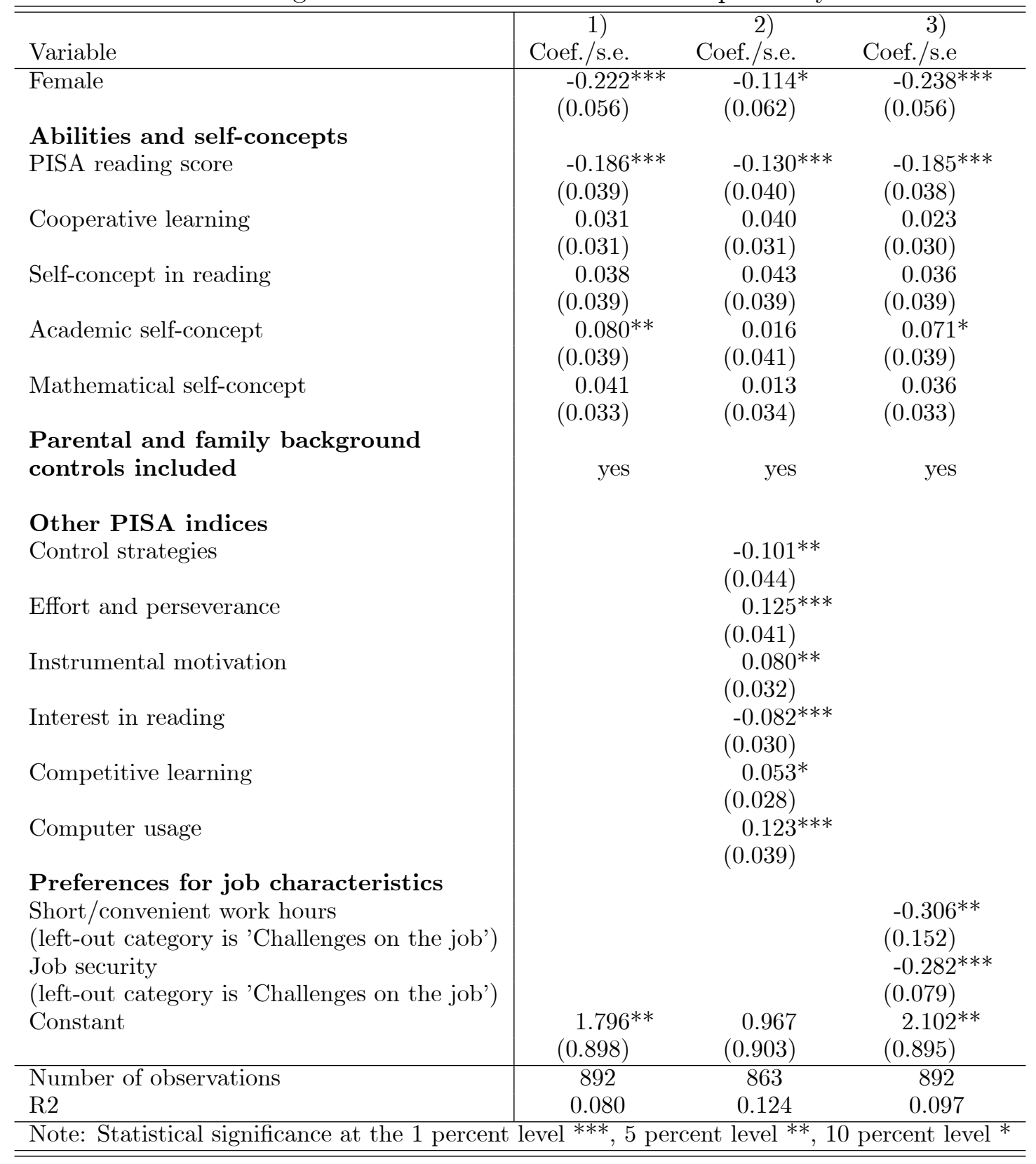


Table 6: OLS Regressions of the Social Factor on Explanatory Variables

\begin{tabular}{|c|c|c|c|}
\hline Variable & $\begin{array}{c}1) \\
\text { Coef./s.e. }\end{array}$ & $\begin{array}{c}2) \\
\text { Coef./s.e. }\end{array}$ & $\begin{array}{c}3) \\
\text { Coef./s.e }\end{array}$ \\
\hline Female & $\begin{array}{l}0.318^{* * *} \\
(0.057)\end{array}$ & $\begin{array}{l}0.283^{* * *} \\
(0.059)\end{array}$ & $\begin{array}{l}0.322^{* * *} \\
(0.058)\end{array}$ \\
\hline Abilities and self-concepts & & & \\
\hline PISA reading score & $\begin{array}{l}-0.098^{* *} \\
(0.039)\end{array}$ & $\begin{array}{l}-0.125^{* * *} \\
(0.041)\end{array}$ & $\begin{array}{l}-0.097^{* *} \\
(0.040)\end{array}$ \\
\hline Cooperative learning & $\begin{array}{l}0.152^{* * *} \\
(0.031)\end{array}$ & $\begin{array}{l}0.143^{* * *} \\
(0.031)\end{array}$ & $\begin{array}{l}0.154^{* * *} \\
(0.031)\end{array}$ \\
\hline Self-concept in reading & $\begin{array}{r}-0.002 \\
(0.040)\end{array}$ & $\begin{array}{r}-0.016 \\
(0.040)\end{array}$ & $\begin{array}{r}-0.002 \\
(0.040)\end{array}$ \\
\hline Academic self-concept & $\begin{array}{r}-0.016 \\
(0.040)\end{array}$ & $\begin{array}{r}0.012 \\
(0.043)\end{array}$ & $\begin{array}{r}-0.016 \\
(0.040)\end{array}$ \\
\hline Mathematical self-concept & $\begin{array}{l}-0.074^{* *} \\
(0.034)\end{array}$ & $\begin{array}{l}-0.062^{*} \\
(0.035)\end{array}$ & $\begin{array}{l}-0.073^{* *} \\
(0.034)\end{array}$ \\
\hline $\begin{array}{l}\text { Parental and family background } \\
\text { controls included }\end{array}$ & yes & yes & yes \\
\hline Other PISA indices & & & \\
\hline Control strategies & & $\begin{array}{l}-0.073^{* *} \\
(0.036)\end{array}$ & \\
\hline Disciplinary climate & & $\begin{array}{l}0.071^{* *} \\
(0.032)\end{array}$ & \\
\hline Engagement in reading & & $\begin{array}{c}0.066^{*} \\
(0.038)\end{array}$ & \\
\hline Control expectations & & $\begin{array}{l}-0.095^{* *} \\
(0.038)\end{array}$ & \\
\hline Preferences for job characteristics & & & \\
\hline Short/convenient work hours & & & 0.151 \\
\hline (left-out category is 'Challenges on the job') & & & $(0.157)$ \\
\hline Job security & & & $\begin{array}{r}0.047 \\
(0.081)\end{array}$ \\
\hline (left-out category is 'Challenges on the job') & 0.171 & 0.176 & $\begin{array}{r}(0.081) \\
0.074\end{array}$ \\
\hline & $(0.917)$ & $(0.917)$ & $(0.921)$ \\
\hline Number of observations & 892 & 885 & 892 \\
\hline $\mathrm{R} 2$ & 0.103 & 0.121 & 0.104 \\
\hline
\end{tabular}




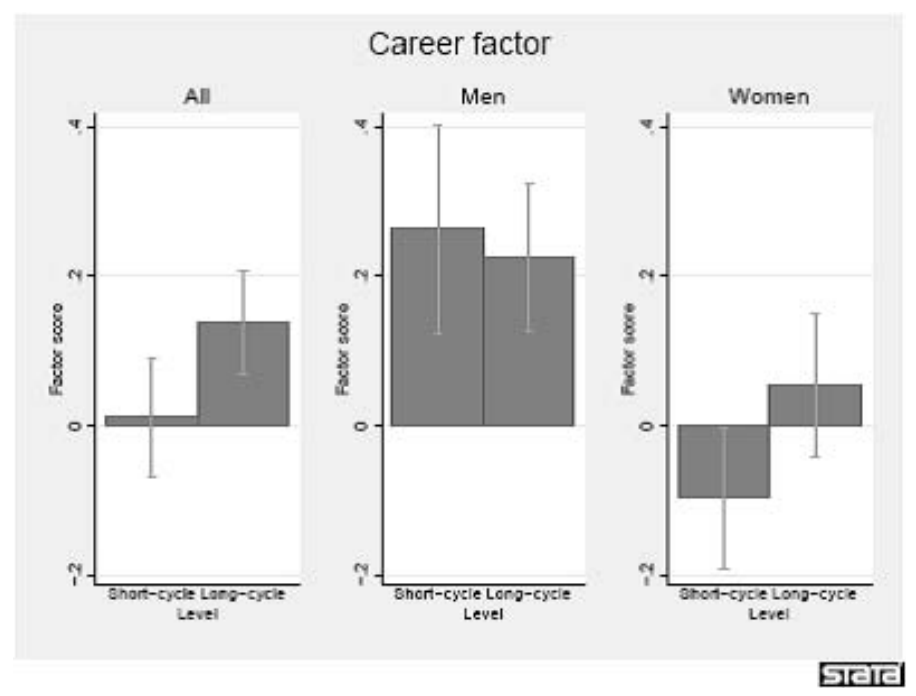

Figure 1: The career factor score by level of education.

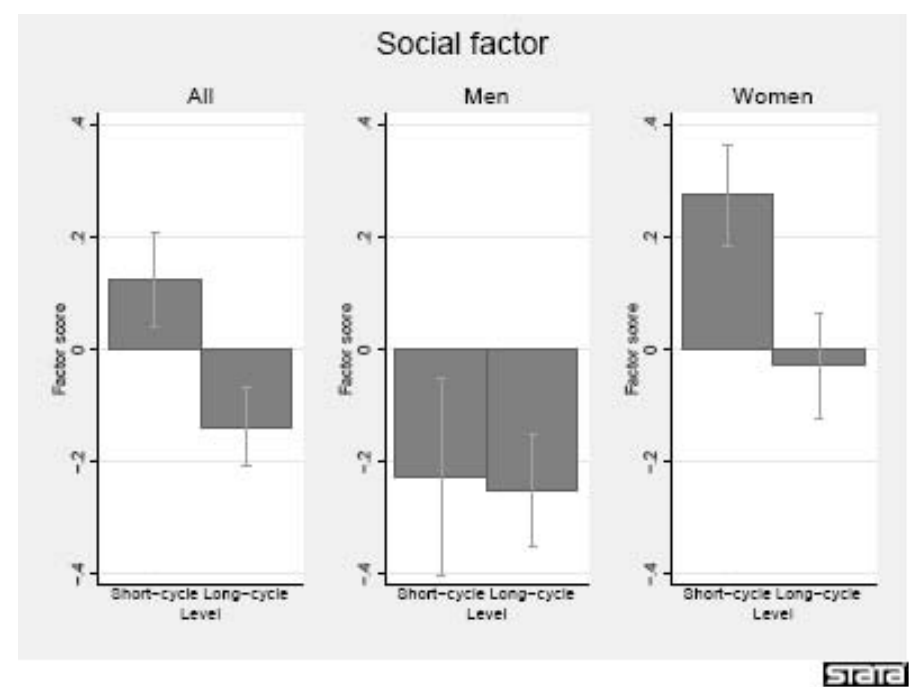

Figure 2: The social factor score by level of education.

average, individuals who choose 'Health sciences' have higher scores on the social factor than those who choose 'Engineering and natural sciences' and 'Business, law and social sciences' educations.

Given our interpretation of the two factors as attachment to two social categories, we have specific expectations about how they are related to educational plans. If the career factor measures the degree of career oriented self-image, we would expect that a high score on this factor increases the planned level of education as well as planned enrollment into fields where wages and social status are generally high, as for example, 'Business, law and social sciences'. Furthermore, if the social factor measures the degree of a socially oriented self-image, one would expect that a higher value of the social factor increases enrollment into fields where the focus is on people, personal services and collaboration, such as in 'Education and humanities' and 'Health sciences'. The observed patterns are thus consistent with what we would expect given our interpretation of the factors. 




Figure 3: The career factor score by field of education.



Figure 4: The social factor score by field of education. 


\subsection{Empirical Analyses of the Choice of Level and Field of Education}

We start this section by presenting the results from the regressions for the choice of level and field of education which include the factors as continuous variables. This is followed by results from regressions of a conditional logit model which allows us to quantify the effect of the factors in monetary values.

\subsubsection{Level of Education}

To analyze the planned level of education, we use a logit model of the choice of long-cycle higher education ( $5+$ year college) vs. short- and medium-cycle education (2-4 year college). Table 7 displays the marginal effects from 5 different specifications and their standard errors, which are estimated using bootstrapping.

In the first specification, only the two factors and a gender dummy are included. We gradually add more explanatory variables: Specification 2 adds ability measures, and Specification 3 adds measures of family background. The results of this latter specification estimated separately by gender are shown in columns 4 and 5 .

In general, the career factor is positively related to choosing a long-cycle higher education and the social factor is negatively related. In the first specification, the marginal effect of the social factor on the probability of enrolling in long-cycle education is -0.08 , whereas the career factor is statistically insignificant. Adding abilities and self-concepts slightly decreases the size of the marginal effect of the social factor and renders the marginal effect of the career factor positive and statistically significant. As one would expect, the marginal effect of the reading score on the probability of enrollment in long-cycle education is positive and very well-determined. The mathematical self-concept is the only self-concept that is statistically significant in these specifications, and the marginal effect is positive. When parental and family background variables are added, the marginal effects of both factors increase in size. Based on specification 3), which is the preferred specification, these results can be interpreted as being in support of the model set up in section 3. More specifically, they suggest that prescribed behavior for the career oriented category is to choose a long-cycle higher education while prescribed behavior for the socially oriented category is to choose a short- or mediumcycle higher education. In this context it should be noted that many short- and medium-cycle higher educations are education or health related.

The last two columns in table 7 , however, show that these results hold only for women - none of the factors are statistically significant for men. As a consequence, the marginal effects of the factors for women are even higher: 0.09 for the career factor and -0.14 for the social factor. This means that a one standard deviation increase in the career factor would induce $9 \%$ of women to switch from a short- and medium-cycle to a long-cycle higher education, whereas a one standard deviation increase in the social factor would induce $14 \%$ of the women to switch from long-cycle to short- or medium-cycle higher educations. Women's choice of long-cycle education is also positively influenced by their reading score and self-concept in math.

For men, only two of the explanatory variables are statistically significant at the $10 \%$ level (the reading score and being an only child), and both have much smaller marginal effects than for women. The explanatory power of the regression is low. 
Table 7: Logit Analysis of the Choice of Long-Cycle Higher Education

\begin{tabular}{|c|c|c|c|c|c|}
\hline Variable & $\begin{array}{c}1) \\
\mathrm{ME} / \text { s.e. }\end{array}$ & $\begin{array}{c}\text { 2) } \\
\mathrm{ME} / \text { s.e. }\end{array}$ & $\begin{array}{c}3) \\
\mathrm{ME} / \text { s.e. }\end{array}$ & $\begin{array}{c}4) \\
\text { Men } \\
\text { ME/s.e. }\end{array}$ & $\begin{array}{c}5) \\
\text { Women } \\
\text { ME/s.e. }\end{array}$ \\
\hline Career factor & $\begin{array}{r}0.031 \\
(0.023)\end{array}$ & $\begin{array}{c}0.050^{* *} \\
(0.024)\end{array}$ & $\begin{array}{c}0.054^{* *} \\
(0.024)\end{array}$ & $\begin{array}{r}0.006 \\
(0.038)\end{array}$ & $0.089^{* *}$ \\
\hline Social factor & $\begin{array}{l}-0.077^{* * *} \\
(0.026)\end{array}$ & $\begin{array}{l}-0.057^{* *} \\
(0.027)\end{array}$ & $\begin{array}{l}-0.068^{* *} \\
(0.029)\end{array}$ & $\begin{array}{r}-0.005 \\
(0.033)\end{array}$ & $\begin{array}{l}-0.144^{* * *} \\
(0.043)\end{array}$ \\
\hline Female & $\begin{array}{l}-0.158^{* * *} \\
(0.034)\end{array}$ & $\begin{array}{l}-0.151^{* * *} \\
(0.036)\end{array}$ & $\begin{array}{l}-0.129^{* * *} \\
(0.038)\end{array}$ & & \\
\hline Abilities and self-concepts & & & & & \\
\hline PISA reading score & & $\begin{array}{l}0.136^{* * *} \\
(0.027)\end{array}$ & $\begin{array}{l}0.117^{* * *} \\
(0.028)\end{array}$ & $\begin{array}{c}0.064^{*} \\
(0.037)\end{array}$ & $\begin{array}{l}0.155^{* * *} \\
(0.040)\end{array}$ \\
\hline Cooperative learning & & $\begin{array}{r}-0.028 \\
(0.020)\end{array}$ & $\begin{array}{r}-0.025 \\
(0.021)\end{array}$ & $\begin{array}{r}0.012 \\
(0.030)\end{array}$ & $\begin{array}{r}-0.033 \\
(0.029)\end{array}$ \\
\hline Self-concept in reading & & $\begin{array}{r}0.023 \\
(0.026)\end{array}$ & $\begin{array}{r}0.022 \\
(0.027)\end{array}$ & $\begin{array}{r}0.002 \\
(0.037)\end{array}$ & $\begin{array}{r}0.039 \\
(0.037)\end{array}$ \\
\hline Academic self-concept & & $\begin{array}{r}-0.009 \\
(0.026)\end{array}$ & $\begin{array}{r}-0.012 \\
(0.026)\end{array}$ & $\begin{array}{r}-0.011 \\
(0.037)\end{array}$ & $\begin{array}{r}-0.019 \\
(0.037)\end{array}$ \\
\hline Mathematical self-concept & & $\begin{array}{l}0.054^{* *} \\
(0.022)\end{array}$ & $\begin{array}{l}0.062^{* * *} \\
(0.023)\end{array}$ & $\begin{array}{r}0.012 \\
(0.035)\end{array}$ & $\begin{array}{l}0.088^{* * *} \\
(0.030)\end{array}$ \\
\hline $\begin{array}{l}\text { Family and parental background } \\
\text { controls included }\end{array}$ & no & no & yes & yes & yes \\
\hline Number of observations & 892 & 892 & 892 & 366 & 526 \\
\hline Pseudo R2 & 0.039 & 0.078 & 0.111 & 0.049 & 0.156 \\
\hline Log-likelihood & -582.326 & -558.531 & -538.438 & -214.316 & -307.722 \\
\hline $\begin{array}{l}\text { Notes: } \\
\text { 1) Statistical significance at the } 1 \mathrm{p} \\
\text { 2) Standard errors for the career an }\end{array}$ & level **: & ercent &, 10 & $\begin{array}{l}\text { evel *. } \\
\text { ng. }\end{array}$ & \\
\hline
\end{tabular}

We conclude from this analysis that both identity related factors are important for the choice of educational level for women, but seem to have no effect for men's choice.

\subsubsection{Field of Education}

In order to analyze the choice of the field of education, we apply a multinomial logit model to the field categories. As described in the data section, individuals are grouped according to their educational plans into four broad categories: 'Education and humanities', 'Engineering and natural sciences', 'Business, law and social sciences', and 'Health sciences'. Tables 8-12 present the results from multinomial logit analyses of the choice of the field of education with 'Business, law and social sciences' as the reference category. Again, we report the marginal effects and standard errors.

As before, in the first specification only the two factors and an indicator variable for gender are included. As one might expect, women have a higher probability of choosing 'Education and humanities' or 'Health sciences' and a lower probability of choosing 'Engineering and natural sciences'. The general pattern is the same across the specifications in tables 8-10: a higher career factor is negatively related to choosing 'Education and humanities' and positively related to choosing 'Business, law and social sciences'. There is no statistically significant effect for choosing 'Engineering and natural sciences' or 'Health sciences'. Individuals with higher social factors are more likely to choose 'Health sciences', and less likely to choose 'Business, law, and social sciences'. As before, there is no statistically significant effect for 
'Engineering and natural sciences'. There is a positive effect of the social factor on choosing 'Education and humanities', but when ability measures are added, this effect becomes statistically insignificant. With this one exception, the sizes of the effects are similar across specifications. More directly, a one standard deviation increase in the career factor decreases the probability of choosing 'Education and humanities' over other fields by 6.5 percentage points. This means that an increase in the career factor by one standard deviation would move $6.5 \%$ of the population from 'Education and humanities' to primarily 'Business, law and social sciences'.

When we add family background, the reading score becomes less statistically significant. However, there is a small and negative marginal effect of the reading score on the probability of choosing both 'Education and humanities' and 'Health sciences' countered by a positive marginal effect on the probability of choosing 'Business, law and social sciences'. The marginal effect of the cooperative learning index on the probability of choosing 'Engineering and natural sciences' is negative. The most important ability variable for the choice of field appears to be the mathematical self-concept. An individual with a higher mathematical selfconcept is less likely to be in the 'Education and humanities' category, and the marginal effect is quite large at $-0.093 .^{20}$ The opposite is true for 'Engineering and natural sciences'. The family background variables are generally not statistically significant.

Comparing the results for the choice of the educational level and the results for the choice of educational field, we see that the pseudo R-squares in both cases are around .11. However, in the logit model for the choice of level, we find that the effect of ability is much stronger than the effect of the factors, whereas in the multinomial logit model for the choice of field, we find that the effect of ability and the effect of the factors are of the same order of magnitude. Hence, we conclude that the identity related issues are relatively more important for the choice of field than for the choice of level. ${ }^{21}$

Tables 11 and 12 present the results of a multinomial logit specification similar to that in table 10 with separate estimations for men and women. There are some disparities in the sizes of the marginal effects, but the overall pattern is somewhat similar to the results for the entire sample. There are, however, some interesting gender differences. Women who score higher on the career factor are now more likely to choose 'Engineering and natural sciences' , while the career factor has no effect for men on choosing this field. Conversely, for men, but not for women, the career factor is positively related to choosing 'Business, law and social sciences'; for choosing 'Health sciences', the social factor is only an important determinant for women.

When they do matter, the factors are economically significant. Increasing the career factor by one standard deviation would move $7.3 \%$ of the men from 'Education and humanities' to mainly 'Business, law and social sciences', whereas a similar exercise for women would move $5.3 \%$ of the women from 'Education and humanities' into other fields (mainly 'Engineering and natural sciences'). A one standard deviation increase in the social factor would move $8.8 \%$ of

\footnotetext{
${ }^{20}$ The s.d. of the measure of mathematical self-concept is about one, therefore, the effect is rather large.

${ }^{21}$ From specification 1) to 2) where we add ability variables, the pseudo R-squared increases by .04 in the logit model for length (table 7), whereas the similar contribution in the multinomial logit for field increases by .02 (tables 8 and 9). A qualitatively similar conclusion is reached when the variables are added in the opposite order and when the operation is performed separately by gender.
} 
Table 8: Multinomial Logit Analysis of the Choice of Field of Higher Education

\begin{tabular}{|c|c|c|c|c|}
\hline Variable & $\begin{array}{c}\text { Education } \\
\text { and } \\
\text { humanities } \\
\text { ME/s.e. }\end{array}$ & $\begin{array}{c}\text { Engineering } \\
\text { and } \\
\text { natural } \\
\text { sciences } \\
\text { ME/s.e. }\end{array}$ & $\begin{array}{c}\text { Business, } \\
\text { law, and } \\
\text { social } \\
\text { sciences } \\
\text { ME/s.e. }\end{array}$ & $\begin{array}{c}\text { Health } \\
\text { sciences }\end{array}$ \\
\hline Career factor & $\begin{array}{l}-0.065^{* * *} \\
(0.019)\end{array}$ & $\begin{array}{r}0.021 \\
(0.019)\end{array}$ & $\begin{array}{c}0.057^{* *} \\
(0.023)\end{array}$ & $\begin{array}{r}-0.013 \\
(0.016)\end{array}$ \\
\hline Social factor & $\begin{array}{c}0.037^{*} \\
(0.020)\end{array}$ & $\begin{array}{r}0.006 \\
(0.020)\end{array}$ & $\begin{array}{l}-0.091^{* * *} \\
(0.020)\end{array}$ & $\begin{array}{c}0.048^{* * *} \\
(0.018)\end{array}$ \\
\hline Female & $\begin{array}{l}0.125^{* * *} \\
(0.030)\end{array}$ & $\begin{array}{l}-0.297 \text { *** } \\
(0.031)\end{array}$ & $\begin{array}{r}-0.011 \\
(0.032) \\
\end{array}$ & $\begin{array}{c}0.183^{* * *} \\
(0.025)\end{array}$ \\
\hline $\begin{array}{l}\text { Number of observations } \\
\text { Pseudo R2 } \\
\text { Log-likelihood }\end{array}$ & & $\begin{array}{r}8 \\
0 . \\
-113\end{array}$ & & \\
\hline $\begin{array}{l}\text { Notes: } \\
\text { 1) Statis }\end{array}$ & & sa & el & vel \\
\hline
\end{tabular}

Table 9: Multinomial Logit Analysis of the Choice of Field of Higher Education

\begin{tabular}{|c|c|c|c|c|}
\hline 2) & $\begin{array}{l}\text { Education } \\
\text { and hu- } \\
\text { manities }\end{array}$ & $\begin{array}{l}\text { Engineering } \\
\text { and } \\
\text { natural } \\
\text { sciences }\end{array}$ & $\begin{array}{c}\text { Business, } \\
\text { law, and } \\
\text { social } \\
\text { sciences }\end{array}$ & $\begin{array}{c}\text { Health } \\
\text { sciences }\end{array}$ \\
\hline Variable & ME/s.e. & ME/s.e. & ME/s.e. & ME/s.e. \\
\hline Career factor & $\begin{array}{l}-0.070^{* * *} \\
(0.020)\end{array}$ & $\begin{array}{r}0.023 \\
(0.019)\end{array}$ & $\begin{array}{c}0.065^{* * *} \\
(0.023)\end{array}$ & $\begin{array}{l}-0.018 \\
(0.018)\end{array}$ \\
\hline Social factor & $\begin{array}{r}0.025 \\
(0.020)\end{array}$ & $\begin{array}{r}0.020 \\
(0.021)\end{array}$ & $\begin{array}{l}-0.092^{* * *} \\
(0.022)\end{array}$ & $\begin{array}{c}0.047^{* * *} \\
(0.018)\end{array}$ \\
\hline Female & $\begin{array}{l}0.105^{* * *} \\
(0.032)\end{array}$ & $\begin{array}{l}-0.268^{* * *} \\
(0.033)\end{array}$ & $\begin{array}{r}-0.038 \\
(0.035)\end{array}$ & $\begin{array}{l}0.200^{* * *} \\
(0.026)\end{array}$ \\
\hline Abilities and self- & & & & \\
\hline PISA reading & $\begin{array}{l}-0.052^{* *} \\
(0.024)\end{array}$ & $\begin{array}{r}0.017 \\
(0.022)\end{array}$ & $\begin{array}{c}0.064^{* * *} \\
(0.024)\end{array}$ & $\begin{array}{r}-0.029 \\
(0.020)\end{array}$ \\
\hline Cooperative learning & $\begin{array}{r}0.004 \\
(0.018)\end{array}$ & $\begin{array}{c}-0.031^{*} \\
(0.018)\end{array}$ & $\begin{array}{r}0.014 \\
(0.019)\end{array}$ & $\begin{array}{r}0.014 \\
(0.015)\end{array}$ \\
\hline Self-concept in reading & $\begin{array}{r}-0.010 \\
(0.024)\end{array}$ & $\begin{array}{r}-0.028 \\
(0.023)\end{array}$ & $\begin{array}{l}0.062^{* *} \\
(0.025)\end{array}$ & $\begin{array}{r}-0.024 \\
(0.020)\end{array}$ \\
\hline Academic self-concept & $\begin{array}{c}0.043^{*} \\
(0.023)\end{array}$ & $\begin{array}{r}-0.016 \\
(0.023)\end{array}$ & $\begin{array}{l}-0.055^{* *} \\
(0.025)\end{array}$ & $\begin{array}{r}0.029 \\
(0.020)\end{array}$ \\
\hline Mathematical self-concept & $\begin{array}{l}-0.093^{* * *} \\
(0.019)\end{array}$ & $\begin{array}{c}0.078^{* * *} \\
(0.021)\end{array}$ & $\begin{array}{r}0.005 \\
(0.021) \\
\end{array}$ & $\begin{array}{r}0.010 \\
(0.017) \\
\end{array}$ \\
\hline $\begin{array}{l}\text { Number of observations } \\
\text { Pseudo R2 } \\
\text { Log-likelihood }\end{array}$ & \multicolumn{4}{|c|}{$\begin{array}{c}0.094 \\
-1110.970\end{array}$} \\
\hline $\begin{array}{l}\text { Notes: } \\
\text { 1) Statistical significance } \\
\text { 2) Standard errors for the }\end{array}$ & ercen &, $0 \mathrm{p}$ & $\begin{array}{l}{ }^{* *}, 10 \\
\operatorname{sing} \mathrm{b}\end{array}$ & $\begin{array}{l}\text { evel *. } \\
\text { ng. }\end{array}$ \\
\hline
\end{tabular}


Table 10: Multinomial Logit Analysis of the Choice of Field of Higher Education

\begin{tabular}{|c|c|c|c|c|}
\hline 3) & $\begin{array}{l}\text { Education } \\
\text { and } \\
\text { human- } \\
\text { ities }\end{array}$ & $\begin{array}{l}\text { Engineering } \\
\text { and } \\
\text { natural } \\
\text { sciences }\end{array}$ & $\begin{array}{l}\text { Business, } \\
\text { law, } \\
\text { and } \\
\text { social } \\
\text { sciences }\end{array}$ & $\begin{array}{l}\text { Health } \\
\text { sciences }\end{array}$ \\
\hline Variable & ME/s.e. & ME/s.e. & ME/s.e. & ME/s.e. \\
\hline Career factor & $\begin{array}{l}-0.069^{* * *} \\
(0.021)\end{array}$ & $\begin{array}{r}0.023 \\
(0.020)\end{array}$ & $\begin{array}{c}0.062^{* *} \\
(0.024)\end{array}$ & $\begin{array}{c}-0.016 \\
(0.019)\end{array}$ \\
\hline Social factor & $\begin{array}{r}0.024 \\
(0.021)\end{array}$ & $\begin{array}{r}0.019 \\
(0.021)\end{array}$ & $\begin{array}{l}-0.091^{* * *} \\
(0.023)\end{array}$ & $\begin{array}{l}0.048^{* * *} \\
(0.018)\end{array}$ \\
\hline Female & $\begin{array}{l}0.098^{* * *} \\
(0.033)\end{array}$ & $\begin{array}{l}-0.267^{* * *} \\
(0.034)\end{array}$ & $\begin{array}{r}-0.037 \\
(0.036)\end{array}$ & $\begin{array}{l}0.206^{* * *} \\
(0.027)\end{array}$ \\
\hline Abilities and self-concepts & & & & \\
\hline PISA reading score & $\begin{array}{c}-0.046^{*} \\
(0.024)\end{array}$ & $\begin{array}{r}0.020 \\
(0.023)\end{array}$ & $\begin{array}{c}0.061^{* *} \\
(0.025)\end{array}$ & $\begin{array}{c}-0.034^{*} \\
(0.021)\end{array}$ \\
\hline Cooperative learning & $\begin{array}{r}0.006 \\
(0.019)\end{array}$ & $\begin{array}{l}-0.033^{*} \\
(0.018)\end{array}$ & $\begin{array}{r}0.011 \\
(0.020)\end{array}$ & $\begin{array}{r}0.016 \\
(0.016)\end{array}$ \\
\hline Self-concept in reading & $\begin{array}{r}-0.011 \\
(0.024)\end{array}$ & $\begin{array}{r}-0.030 \\
(0.023)\end{array}$ & $\begin{array}{l}0.064^{* *} \\
(0.025)\end{array}$ & $\begin{array}{r}-0.023 \\
(0.020)\end{array}$ \\
\hline Academic self-concept & $\begin{array}{c}0.044^{*} \\
(0.024)\end{array}$ & $\begin{array}{r}-0.016 \\
(0.023)\end{array}$ & $\begin{array}{l}-0.057^{* *} \\
(0.025)\end{array}$ & $\begin{array}{r}0.030 \\
(0.020)\end{array}$ \\
\hline Mathematical self-concept & $\begin{array}{l}-0.095^{* * *} \\
(0.019)\end{array}$ & $\begin{array}{l}0.083^{* * *} \\
(0.021)\end{array}$ & $\begin{array}{r}0.004 \\
(0.022)\end{array}$ & $\begin{array}{r}0.008 \\
(0.017)\end{array}$ \\
\hline $\begin{array}{l}\text { Family and parental background } \\
\text { controls included }\end{array}$ & \multicolumn{4}{|c|}{ yes } \\
\hline Number of observations & \multicolumn{4}{|c|}{892} \\
\hline Pseudo R2 & \multirow{2}{*}{\multicolumn{4}{|c|}{$\begin{array}{c}0.107 \\
-1095.075\end{array}$}} \\
\hline Log-likelihood & & & & \\
\hline
\end{tabular}


Table 11: Multinomial Logit Analysis of the Choice of Field of Higher Education - Men

\begin{tabular}{|c|c|c|c|c|}
\hline$\overline{4)}$ & $\begin{array}{l}\text { Education } \\
\text { and hu- } \\
\text { manities }\end{array}$ & $\begin{array}{l}\text { Engineering } \\
\text { and } \\
\text { natural } \\
\text { sciences }\end{array}$ & $\begin{array}{c}\text { Business, } \\
\text { law, and } \\
\text { social } \\
\text { sciences }\end{array}$ & $\begin{array}{c}\text { Health } \\
\text { sciences }\end{array}$ \\
\hline Variable & ME/s.e. & ME/s.e. & ME/s.e. & ME/s.e. \\
\hline Career factor & $\begin{array}{l}-0.073^{* *} \\
(0.032)\end{array}$ & $\begin{array}{r}-0.013 \\
(0.046)\end{array}$ & $\begin{array}{l}0.088^{* *} \\
(0.041)\end{array}$ & $\begin{array}{r}-0.002 \\
(0.014)\end{array}$ \\
\hline Social factor & $\begin{array}{r}0.014 \\
(0.025)\end{array}$ & $\begin{array}{r}0.046 \\
(0.047)\end{array}$ & $\begin{array}{l}-0.084^{* *} \\
(0.039)\end{array}$ & $\begin{array}{r}0.024 \\
(0.016)\end{array}$ \\
\hline Abilities and self-concepts & & & & \\
\hline PISA reading sco & $\begin{array}{r}-0.029 \\
(0.030)\end{array}$ & $\begin{array}{r}-0.022 \\
(0.041)\end{array}$ & $\begin{array}{r}0.045 \\
(0.038)\end{array}$ & $\begin{array}{r}0.007 \\
(0.020)\end{array}$ \\
\hline Cooperative learning & $\begin{array}{c}0.042^{*} \\
(0.024)\end{array}$ & $\begin{array}{r}-0.053 \\
(0.035)\end{array}$ & $\begin{array}{r}0.020 \\
(0.032)\end{array}$ & $\begin{array}{r}-0.010 \\
(0.017)\end{array}$ \\
\hline Self-concept in reading & $\begin{array}{r}-0.003 \\
(0.030)\end{array}$ & $\begin{array}{r}-0.062 \\
(0.043)\end{array}$ & $\begin{array}{r}0.059 \\
(0.039)\end{array}$ & $\begin{array}{r}0.007 \\
(0.020)\end{array}$ \\
\hline Academic self-concept & $\begin{array}{c}0.057^{*} \\
(0.031)\end{array}$ & $\begin{array}{r}-0.029 \\
(0.042)\end{array}$ & $\begin{array}{r}-0.054 \\
(0.040)\end{array}$ & $\begin{array}{r}0.026 \\
(0.021)\end{array}$ \\
\hline Mathematical self-concept & $\begin{array}{l}-0.073^{* * *} \\
(0.027)\end{array}$ & $\begin{array}{l}0.117^{* * *} \\
(0.043)\end{array}$ & $\begin{array}{r}-0.054 \\
(0.038)\end{array}$ & $\begin{array}{r}0.010 \\
(0.021)\end{array}$ \\
\hline $\begin{array}{l}\text { Family and parental background } \\
\text { controls included }\end{array}$ & \multicolumn{4}{|c|}{ yes } \\
\hline $\begin{array}{l}\text { Number of observations } \\
\text { Pseudo R2 } \\
\text { Log-likelihood }\end{array}$ & & $\begin{array}{r}366 \\
0.08 \\
-413.5\end{array}$ & & \\
\hline $\begin{array}{l}\text { Notes: } \\
\text { 1) Statistical significance }\end{array}$ & evel $\pi+$ & tilt & $0 \mathrm{p}$ & \\
\hline
\end{tabular}

the women from 'Business, law and social sciences' to mainly 'Health sciences'. Similarly, 8.4\% of the men would be moved from 'Business, law and social, sciences' into other fields. These findings are closely in line with those by Lackland and De Lisi (2001). ${ }^{22}$ These conclusions about the effect of the factor scores are robust to running the factors analysis separately by gender (results not shown). The results are also robust to conducting the same analysis with four indicator variables for low and high scores in the two factors instead of the continuous values for the two factors (results not shown). ${ }^{23}$

In conclusion, the analysis on the effect of factors on choice of educational field suggests that prescribed behavior for the career oriented category is to enroll in educations 'Business, law and social sciences', and to not enroll in educations in 'Education and humanities'. Prescribed behavior for the socially oriented category is to enroll in educations in 'Health sciences' and not in 'Business, law and social science'. The fact that we find that the factors are indeed - statistically and economically - important for the choice of level and field of education suggests that identity-related payoffs are important for the choice of education. ${ }^{24}$

\footnotetext{
${ }^{22}$ Lackland and De Lisi (2001) select six specific college majors (Engineering, Physics, Math, English, Education and Nursing). They find that a higher score on their factor 'humanitarian concerns' increases the probability of choosing the helping professions (Education and Nursing), and decreases the probability of choosing Science (Engineering and Physics). A higher score on their factor 'utility value' increases the probability of being in the Science professions and decreases the probability of being in the Helping professions.

${ }^{23}$ While the results are similar, they also show that the relative size of one factor compared to the other is important, so that there are no statistically significant differences between those scoring low on both factors and those scoring high on both factors.

${ }^{24}$ Including dummies for the five most important variables for each factor yields similar qualitative results.
} 
Table 12: Multinomial Logit Analysis of the Choice of Field of Higher Education - Women

\begin{tabular}{|c|c|c|c|c|}
\hline Variable & $\begin{array}{l}\text { Education } \\
\text { and hu- } \\
\text { manities } \\
\mathrm{ME} / \text { s.e. }\end{array}$ & $\begin{array}{l}\text { Engineering } \\
\text { and } \\
\text { natural } \\
\text { sciences } \\
\mathrm{ME} / \mathrm{s.e} \text {. }\end{array}$ & $\begin{array}{c}\text { Business, } \\
\text { law, and } \\
\text { social } \\
\text { sciences } \\
\text { ME/s.e. }\end{array}$ & $\begin{array}{l}\text { Health } \\
\text { sciences }\end{array}$ \\
\hline Career factor & $-0.053^{*}$ & $0.032^{*}$ & 0.037 & -0.016 \\
\hline & $(0.029)$ & $(0.019)$ & $(0.032)$ & $(0.030)$ \\
\hline Social factor & 0.018 & -0.001 & $-0.088^{* * *}$ & $0.072^{* *}$ \\
\hline & $(0.029)$ & $(0.020)$ & $(0.031)$ & $(0.031)$ \\
\hline Abilities and self-concepts & & & & \\
\hline PISA reading score & $\begin{array}{r}-0.045 \\
(0.034)\end{array}$ & $\begin{array}{r}0.027 \\
(0.022)\end{array}$ & $\begin{array}{l}0.073^{* *} \\
(0.032)\end{array}$ & $\begin{array}{l}-0.056^{*} \\
(0.033)\end{array}$ \\
\hline Cooperative learning & -0.029 & -0.010 & 0.015 & 0.025 \\
\hline Self-concept in reading & $\begin{array}{r}-0.010 \\
(0.033)\end{array}$ & $\begin{array}{r}-0.008 \\
(0.023)\end{array}$ & $\left(0.069^{* *}\right.$ & $\begin{array}{l}-0.051 \\
(0.032)\end{array}$ \\
\hline Academic self-concept & $\begin{array}{r}0.018 \\
(0.032)\end{array}$ & $\begin{array}{r}-0.002 \\
(0.023)\end{array}$ & $\begin{array}{r}-0.049 \\
(0.031)\end{array}$ & $\begin{array}{r}0.033 \\
(0.031)\end{array}$ \\
\hline Mathematical self-concept & $\begin{array}{l}-0.098^{* * *} \\
(0.026)\end{array}$ & $\begin{array}{l}0.049^{* *} \\
(0.019)\end{array}$ & $\begin{array}{r}0.024 \\
(0.025)\end{array}$ & $\begin{array}{r}0.025 \\
(0.026)\end{array}$ \\
\hline $\begin{array}{l}\text { Family and parental background } \\
\text { controls included }\end{array}$ & \multicolumn{4}{|c|}{ yes } \\
\hline Number of observations & \multicolumn{4}{|c|}{526} \\
\hline Pseudo R2 & \multicolumn{4}{|c|}{0.076} \\
\hline Log-likelihood & \multicolumn{4}{|c|}{-653.481} \\
\hline $\begin{array}{l}\text { Notes: } \\
\text { 1) Statistical significance at the } 1 \text { p } \\
\text { 2) Standard errors for the career an }\end{array}$ & $\begin{array}{l}\text { level } * * * \\
\text { al factors }\end{array}$ & stimated & $\begin{array}{l}*, 10 \text { perc } \\
\text { hg bootst }\end{array}$ & vel *. \\
\hline
\end{tabular}

\subsubsection{The Monetary Value of Identity Payoffs}

In order to quantify the identity payoffs suggested by the above analyses, we estimate a conditional logit model including predicted wage incomes for each individual. To predict wage incomes, we use estimated coefficients from wage regressions on a $10 \%$ sample of the Danish population. The sample used in this wage regressions is restricted to a cross-section of individuals who in 2003 belonged to one of the four educational fields defined earlier. This sample was further restricted in order to be comparable to our sample to only high school graduates, individuals with a GPA greater than or equal to $6.0^{25}$, who were younger than age 22 at high school graduation, and who are not currently enrolled in an education. As wage measure total annual wages are used, and observations with observed unemployment during the year are included. Wages are trimmed at $2.5 \%$ in each end of the distribution to provide a better fit. The regressions are run separately by educational field and gender. A quadratic in experience and high school GPA are included as explanatory variables. The GPA is included in order to capture potential ability differences and provide individual-specific variation.

Based on these wage regressions, we predict counterfactual annual wage incomes for the higher education sample, using GPA and experience set equal to ten years. The sample size is now slightly reduced due to missing GPA for some individuals. The level of experience is chosen to represent the identity payoffs associated with somewhat mature wages in the educational fields. The predicted wage incomes are alternative-specific. Without the

\footnotetext{
${ }^{25}$ The grading scale used in Denmark is a 13-point scale. Grades equal to or above 6 are passing grades.
} 
alternative-specific wage incomes, the conditional logit model simply replicates the results of the multinomial logit models reported earlier. In table 13, the results are shown for the entire sample and for men and women separately. Similar to before, an increase in the career factor decreases the latent utility of choosing 'Education and humanities' relative to 'Business, law and social sciences', and an increase in the social factor increases the latent utility of all other fields relative to 'Business, law and social sciences'. As before results differ across gender.

The interpretation of the monetary value (MV) is that e.g. an increase in relative wage income of US $\$ 5,052$ is needed to induce a change in latent utility for 'Health sciences' relative to 'Business, law and social sciences' corresponding to a one standard deviation increase in the social factor. Similarly, a decrease in relative wage income of US $\$ 4,751$ is needed to induce a change in latent utility for 'Education and humanities' relative to 'Business, law and social sciences' corresponding to a one standard deviation increase in the career factor. Both of these numbers correspond to about $11 \%$ of average predicted wage income in the fields of 'Health sciences' and 'Education and humanities', respectively. Thus, identity payoffs in career choices appear to be substantial.

The monetary values differ across gender, but in general the pattern is similar, except for the negative MV for men associated with the career factor and the field of 'Engineering and natural sciences' and the positive MV for women. The estimated coefficient is insignificant for women, so one should probably not put too much weight on these results, but they suggest that career-oriented women are more likely to choose 'Engineering and natural sciences' over 'Business, law and social sciences' than career-oriented men, as found earlier.

Table 13: Conditional Logit Analysis - The Monetary Value of Identity Payoffs

\begin{tabular}{|c|c|c|c|c|c|c|}
\hline \multirow[b]{2}{*}{ Variable } & \multicolumn{2}{|l|}{$\begin{array}{l}\text { 1) } \\
\text { All }\end{array}$} & \multicolumn{2}{|l|}{$\begin{array}{c}\text { 2) } \\
\text { Men }\end{array}$} & \multicolumn{2}{|c|}{$\begin{array}{c}3) \\
\text { Women }\end{array}$} \\
\hline & Coef./s.e. & MV & Coef./s.e. & MV & Coef./s.e. & MV \\
\hline Career factor & & & & & & \\
\hline Education and humanities & $\begin{array}{l}-0.459^{* * *} \\
(0.132)\end{array}$ & $-4,751$ & $\begin{array}{l}-0.798^{* * *} \\
(0.236)\end{array}$ & $-5,726$ & $\begin{array}{l}-0.303^{*} \\
(0.166)\end{array}$ & $-4,239$ \\
\hline $\begin{array}{l}\text { Engineering and natural } \\
\text { sciences }\end{array}$ & $\begin{array}{r}-0.078 \\
(0.131)\end{array}$ & -812 & $\begin{array}{l}-0.356^{* *} \\
(0.182)\end{array}$ & $-2,558$ & $\begin{array}{r}0.212 \\
(0.212)\end{array}$ & 2,976 \\
\hline Health sciences & $\begin{array}{l}-0.273^{*} \\
(0.142)\end{array}$ & $-2,827$ & $\begin{array}{r}-0.307 \\
(0.305)\end{array}$ & $-2,203$ & $\begin{array}{r}-0.159 \\
(0.169)\end{array}$ & $-2,231$ \\
\hline Social factor & & & & & & \\
\hline Education and humanities & $\begin{array}{l}0.362^{* * *} \\
(0.130)\end{array}$ & 3,749 & $\begin{array}{r}0.339 \\
(0.217)\end{array}$ & 2,430 & $\begin{array}{l}0.374^{* *} \\
(0.170)\end{array}$ & 5,244 \\
\hline $\begin{array}{l}\text { Engineering and natural } \\
\text { sciences }\end{array}$ & $\begin{array}{l}0.346^{* * *} \\
(0.124)\end{array}$ & 3,581 & $\begin{array}{l}0.372^{* *} \\
(0.161)\end{array}$ & 2,668 & $\begin{array}{r}0.286 \\
(0.217)\end{array}$ & 4,010 \\
\hline Health sciences & $\begin{array}{l}0.488^{* * *} \\
(0.143)\end{array}$ & 5,052 & $\begin{array}{l}0.672^{* *} \\
(0.283)\end{array}$ & 4,821 & $\begin{array}{l}0.493^{* * *} \\
(0.175)\end{array}$ & 6,911 \\
\hline Wage income & $\begin{array}{l}1.467^{* * *} \\
(0.338)\end{array}$ & & $\begin{array}{l}2.115^{* * *} \\
(0.722)\end{array}$ & & $\begin{array}{l}1.083^{* *} \\
(0.435)\end{array}$ & \\
\hline Number of individuals & 828 & & 335 & & 493 & \\
\hline \multicolumn{7}{|c|}{$\begin{array}{l}\text { 1) Statistical significance at the } 1 \text { percent level }{ }^{* *}, 5 \text { percent level }{ }^{* *}, 10 \text { percent level }{ }^{*} \text {. } \\
\text { 2) Standard errors are not bootstrapped. } \\
\text { 3) The MV (monetary value) is computed as the change in relative wage income needed for a } \\
\text { corresponding change in relative latent utility given by a one-unit change in the factor. } \\
\text { The value is measured in } 2003 \text { US dollars. The exchange rate used is } 6.5899 \text { DKK/US dollar. } \\
\text { 4) All specifications include the full set of control variables summarized in table } 1 \text {. }\end{array}$} \\
\hline
\end{tabular}




\section{Conclusion}

Classic economic theory has not been able to explain why some people choose educations or occupations that yield low returns but require similar investment. We formulate a model based on Akerlof and Kranton (2000) where the choice of level and field of education is motivated by pecuniary and non-pecuniary factors: People choose a certain level or field of education because it pays off in terms of a higher expected future income and because it pays off in terms of identity due to a more rewarding self-image.

We empirically test the prediction of the model that identity matters for educational choice. We use the Danish part of the PISA 2000 survey which is merged with a follow-up survey containing attitude questions and with register information for the individuals and their parents. A factor analysis based on answers to a range of attitude questions reveals two orthogonal factors which we interpret as two different social categories based on a career oriented and a socially oriented ideal, respectively. We then estimate models of choice of educational level and field, including these two factors as measures of identity as well as other background variables, including measures of ability.

We find that these identity-related factors are important for women's choice between short- and medium-cycle and long-cycle educations, but that they do not matter for men's choices.

With respect to the field of education, we find that career oriented people tend to choose educations within the fields of 'Business, law and social sciences' and not in 'Education and humanities'. This pattern is similar for men and women, although career oriented women tend to be more attracted to 'Engineering and natural sciences' than career oriented men. People who are socially oriented tend to choose a field of education within the humanities, natural or health sciences.

We interpret these findings as an indication that the mentioned educations constitute part of the prescribed behavior for a career-oriented person or a socially-oriented person, respectively. Our analysis indicates that identity payoffs are a non-negligible part of the return to education. We estimate that a one standard deviation increase in the career factor decreases the latent utility of choosing 'Education and humanities' educations relative to 'Business, law and social science' educations by the same amount as a decrease in relative annual wage income of US $\$ 4,751$. Similarly, a one standard deviation increase in the social factor is estimated to increase the latent utility of choosing 'Health science' educations relative to 'Business, law and social science' educations by the same amount as an increase in relative annual wage income of 5,052 $\$$. Furthermore, there are important gender differences in the strength and the signs of the effects, suggesting that identity plays different roles in educational choices for women and men.

Our findings also imply that educational policy and school reforms should not only take into account financial incentives, but also identity related issues. In practice, this may involve information campaigns which allow the youth to make informed choices on which career choices are consistent with their self-images, or it may involve rethinking the educational content or extra-curricular activities to be directed at the type of students that educators want to attract. In the US, these considerations are mainly relevant for institutions of higher 
education, whereas in many European countries it would also be relevant for policy makers because student enrollment capacity is determined by government educational policy.

\section{References}

[1] Akerlof, G. A. and R. E. Kranton (2000), Economics and Identity, Quarterly Journal of Economics 115 (3): 715-753.

[2] Akerlof, G. A. and R. E. Kranton (2002), Identity and Schooling: Some Lessons for the Economics of Education, Journal of Economic Literature 40(4): 1167-1201.

[3] Akerlof, G. A. and R. E. Kranton (2005), Identity and the Economics of Organizations, Journal of Economic Perspectives 19(1): 9-32.

[4] AKF, DPU and SFI-Survey (2001), Forventninger og fardigheder - danske unge $i$ en international sammenligning (Expectations and Skills, the Danish Country Report from PISA 2000), Copenhagen.

[5] Arcidiacono, P. (2004), Ability Sorting and the Returns to College Majors, Journal of Econometrics 121 (1-2): 343-375.

[6] Becker, G. S. (1964), Human Capital. A Theoretical and Empirical Analysis with Special Reference to Education, National Bureau of Economic Research, New York.

[7] Bénabou, R. and J. Tirole (2006), Identity, Dignity, and Taboos: Beliefs as Assets. Working Paper (December).

[8] Benjamin, D. J., J. J. Choi, and A. J. Strickland (2007), Social Identity and Preferences. Population Studies Center Research Report 07-621, University of Michigan Institut for Social Research (April).

[9] Cunha, F. and J. J. Heckman (2007), Identifying and Estimating the Distributions of Ex Post and Ex Ante Returns to Schooling. Forthcoming in Labour Economics.

[10] Dolton, P. J., G. H. Makepeace, and W. van der Klaauw (1989), Occupational Choice and Earnings Determination: The Role of Sample Selection and Non-Pecuniary Factors, Oxford Economic Papers 41(3): 573-594.

[11] Duncan, G. J. (1976), Earnings Functions and Nonpecuniary Benefits, Journal of Human Resources 11(4): 462-483.

[12] Gullason, E. T. (1989), The Consumption Value of Schooling: An Empirical Estimate of One Aspect, Journal of Human Resources 24(2): 287-298.

[13] Heckman, J. J. (1976), A Life-Cycle Model of Earnings, Learning and Consumption, Journal of Political Economy 84: S11-S44.

[14] Hoff, Karla and Priyanka Pandey (2006), Discrimination, Social Identity, and Durable Inequalities, American Economic Review Papers and Proceedings 96(2): 206-211. 
[15] Hogg, M. A., D. J. Terry, and K. M. White (1995), A Tale of Two Theories: A Critical Comparison of Identity Theory with Social Identity Theory, Social Psychology Quarterly 58(4): 255-269.

[16] Jensen, T. P. and Andersen, D. (2006): "Participants in PISA 2000 - Four Years Later", in: J. Mejding and A. Roe, Northern Lights on PISA 2003 - a reflection from the Nordic countries. Copenhagen, Nordic Council of Ministers.

[17] Kodde, D. A. and J. M. M. Ritzen (1984), Integrating Investment and Consumption Motives in a Neoclassical Model of Demand for Education, Kyklos 37: 598-608.

[18] Lackland, A. C. and R. De Lisi (2001), Students' Choices of College Majors That are Gender Traditional and Nontraditional, Journal of College Student Development 42(1): $39-48$.

[19] Lazear, E. (1977), Education: Consumption or Production?, Journal of Political Economy 85(3): 569-597.

[20] OECD (2002a): Manual for the PISA 2000 Database, OECD, Paris.

[21] OECD (2002b): PISA 2000 Technical Report, OECD, Paris.

[22] OECD (2003?): PISA 2003 Data Analysis Manual, OECD, Paris.

[23] Pratt, J., Y. Hiller and J. Mace (1999), Markets and Motivation in Part-time Postgraduate Education, Studies in Higher Education 24(1): 95-107.

[24] Quinn, R. and J. Price (1998), The Demand for Medical Education: An Augmented Human Capital Approach, Economics of Education Review 17(3): 337-347.

[25] Schaafsma, J. (1976), The Consumption and Investment Aspects of the Demand for Education, Journal of Human Resources 11(2): 233-242.

[26] Schultz, T. W. (1963), The Economic Value of Education, Columbia University Press, New York.

[27] Scott, A. (2001), Eliciting GP's preferences for pecuniary and non-pecuniary job characteristics, Journal of Health Economics 20: 329-347.

[28] Spetz, J. (2002), The value of education in a licensed profession: the choice of associate or baccalaureate degrees in nursing, Economics of Education Review 21: 73-85.

[29] Steele, Jennifer R. and Nalini Ambady (2006), "Math is Hard!" The effect of gender priming on women's attitudes, Journal of Experimental Social Psychology 42: 428-436.

[30] Stets, J. E. and P. J. Burke (2000), Identity Theory and Social Identity Theory, Social Psychology Quarterly 63(3): 224-237.

[31] Ward, M. E. and P. J. Sloane (2000), Non-Pecuniary Advantages Versus Pecuniary Disadvantages: Job Satisfaction Among Male and Female Academics in Scottish Universities, Scottish Journal of Economics, 47(3): 273-303. 
[32] Wolfe, B. L. and R. H. Haveman (2003), Social and Nonmarket Benefits from Education in an Advanced Economy. In Yolanda Kodrzycki (Ed.), Education in the 21st Century: Meeting the Challenges of a Changing World, Federal Reserve Bank of Boston: Boston: 96-131. 


\section{A Appendix}

A brief description of the variables used in the empirical analyses is given in table 14 . In addition, we briefly describe some of the indices from PISA below.

The PISA index of family wealth is derived by the OECD from students' reports on: 1) the availability in their home of a dishwasher, a room of their own, educational software, and a link to the internet; and 2) the number of cellular phones, televisions, computers, motor cars and bath rooms at home. Scale scores are standardized Warm estimates, where positive values indicate more and negative values fewer wealth related possessions (see OECD 2002b for more details on the derivation of the scale scores).

The PISA indices of self-concepts are derived by the OECD from students' degree of agreement with statements relating to the subject.

For the self-concept in reading (verbal self-concept) these statements are:

1. I'm hopeless in (test) language class;

2. I learn things quickly in (test) language class;

3. I get good marks in (test) language class.

For the self-concept in math these statements are:

1. I get good marks in mathematics.

2. Mathematics is one of my best subjects.

3. I have always done well in mathematics.

And, finally, for the academic self-concept they are:

1. I learn things quickly in most school subjects.

2. I'm good at most school subjects.

3. I do well in tests in most school subjects.

As in the case of family wealth, the scale scores of each self-concept are standardized (weighted likelihood) Warm estimates, where positive values indicate a higher level of selfconcept in reading and negative values a lower level. The international means of the selfconcepts and wealth are zero with a standard deviation of 1 .

The final ability measure is the PISA score "wleread", a combined reading literacy score (short: reading score), which is also a Warm estimate. The mean is 500 with a standard deviation of 100; in this paper, the reading score is scaled by 0.01 . 
Table 14: Description of Variables

\begin{tabular}{|c|c|c|}
\hline Variable name & Description & Data \\
\hline Female & Gender dummy, 0 is male, 1 is female & REG \\
\hline Abilities and self-concepts & & \\
\hline PISA reading $\mathrm{sc}$ & $\begin{array}{l}\text { Reading score from PISA } 2000 \text { scaled by } 0.01 \\
\text { (WLEREAD) }\end{array}$ & PISA \\
\hline Cooperative learning & Index of cooperative learning (COPLRN) & PISA \\
\hline Self-concept in reading & Index of self-concept in reading (SCVERB) & PISA \\
\hline Academic self-concept & Index of self-concept academics (SCACAD) & PISA \\
\hline Mathematical self-concept & $\begin{array}{l}\text { Index of self-concept in mathematics (MAT- } \\
\text { CON) }\end{array}$ & PISA \\
\hline Family and & & \\
\hline Only child & $\begin{array}{l}\text { Birthorder dummies, left out categories are: } \\
\text { middle and youngest child }\end{array}$ & PISA \\
\hline Oldest child & $\begin{array}{l}\text { Birthorder dummies, left out categories are: } \\
\text { middle and youngest child }\end{array}$ & PISA \\
\hline Nuclear family & $\begin{array}{l}\text { Family structure dummy, left out categories } \\
\text { are: single-parent family, mixed family, and } \\
\text { other }\end{array}$ & PISA \\
\hline Urban & $\begin{array}{l}\text { Dummy for geographical place of residence } \\
\text { (municipality) in 2000, urban (Copenhagen } \\
\text { and Aarhus) rural (residual) }\end{array}$ & REG \\
\hline Higher education - father & $\begin{array}{l}\text { Dummies for father's education, left out cate- } \\
\text { gory is basic and high school }\end{array}$ & REG \\
\hline Vocational education - father & $\begin{array}{l}\text { Dummies for father's education, left out cate- } \\
\text { gory is basic and high school }\end{array}$ & REG \\
\hline Higher education - mother & $\begin{array}{l}\text { Dummies for mother's education, left out cat- } \\
\text { egory is basic and high school }\end{array}$ & REG \\
\hline Vocational education - mother & $\begin{array}{l}\text { Dummies for mother's education, left out cat- } \\
\text { egory is basic and high school }\end{array}$ & REG \\
\hline Measure of parental income & $\begin{array}{l}\text { Parental income measure, defined as } \\
\log ((\text { mother's income }+ \text { father's in- } \\
\text { come }) / \text { sqrt(number of parents present in } \\
\text { register data }))\end{array}$ & REG \\
\hline Fami & Index of family wealth (WEALTH) & PISA \\
\hline $\begin{array}{l}\text { Missing parental education } \\
\text { Other PISA indices }\end{array}$ & Dummy for missing parental education & REG \\
\hline Control stra & gies (CSTRAT & PISA \\
\hline erance & severance (EFFPER) & PISA \\
\hline tivation & umental motivation (INSMOT) & PISA \\
\hline Inte & f interest in reading (INTREA) & PISA \\
\hline earning & etitive learning (COMLRN) & PISA \\
\hline Computer usage & Index of computer usage (COMUSE) & PISA \\
\hline Disciplinary climate & Index of disciplinary climate (DISCLIMA) & PISA \\
\hline reading & engagement in reading (JOYREAD) & PISA \\
\hline Control expectations & Index of control expectations (CEXP) & PISA \\
\hline Preferences for job cl & & \\
\hline Short/convenient work hours & $\begin{array}{l}\text { Dummy for whether short/convenient work } \\
\text { hours are preferred to 'Challenges on the job' }\end{array}$ & PISA-FUS \\
\hline Job security & $\begin{array}{l}\text { Dummy for whether job security is preferred } \\
\text { to 'Challenges on the job' }\end{array}$ & PISA-FUS \\
\hline
\end{tabular}


Table 15: Standardized Scoring Coefficients

\begin{tabular}{|c|c|c|}
\hline \multirow{2}{*}{ Question } & \multicolumn{2}{|c|}{ Factors } \\
\hline & Career & Social \\
\hline \multicolumn{3}{|l|}{ Attitudes towards education } \\
\hline \multicolumn{3}{|l|}{ In your opinion, what makes an education good? } \\
\hline A strictly pre-planned education & 0.111 & 0.044 \\
\hline An education that allows you to combine across existing disciplines & 0.017 & 0.099 \\
\hline An education where you learn by doing & 0.063 & 0.146 \\
\hline $\begin{array}{l}\text { An education that develops your ability and desire to cooperate with other } \\
\text { people }\end{array}$ & 0.047 & 0.198 \\
\hline \multicolumn{3}{|l|}{ Attitudes towards global problems } \\
\hline \multicolumn{3}{|l|}{ What are the important factors in the modern world? } \\
\hline Science and industry will solve our global environment: & 0.117 & 0.013 \\
\hline $\begin{array}{l}\text { The global environmental problems are so big now that technical solutions } \\
\text { alone are not enough. It takes a change of attitudes }\end{array}$ & -0.011 & 0.121 \\
\hline The world is too complex for normal people. We have to rely on experts & 0.066 & 0.047 \\
\hline We have to follow our own intuition. So-called experts are of no help & 0.014 & 0.039 \\
\hline \multicolumn{3}{|l|}{ Attitudes towards career } \\
\hline \multicolumn{3}{|l|}{ How do you imagine your future career will be? } \\
\hline $\begin{array}{l}\text { You know today which sector or field you want to work in. And you will } \\
\text { probably stay there }\end{array}$ & 0.105 & 0.019 \\
\hline $\begin{array}{l}\text { You do not want to be locked into a specific type of job. You want to be able } \\
\text { to switch between different fields }\end{array}$ & 0.026 & 0.125 \\
\hline $\begin{array}{l}\text { One of the most important things in your work life will be a good career } \\
\text { (climbing the ladder) }\end{array}$ & 0.238 & -0.013 \\
\hline $\begin{array}{l}\text { If you want the job of your dreams, you have to specialize. The sooner, the } \\
\text { better }\end{array}$ & 0.201 & 0.048 \\
\hline \multicolumn{3}{|l|}{ Attitudes towards career and spare time } \\
\hline \multicolumn{3}{|l|}{ What is your attitude towards work and spare time? } \\
\hline Your job will give your life meaning & 0.168 & -0.018 \\
\hline $\begin{array}{l}\text { For you, family and spare time will always take priority; work will have to fit } \\
\text { in }\end{array}$ & -0.040 & 0.117 \\
\hline Most of your friends will probably be people you meet through work & 0.095 & -0.003 \\
\hline You are against mixing work and spare time / family & 0.028 & 0.040 \\
\hline \multicolumn{3}{|l|}{ Attitudes towards competition in society } \\
\hline \multicolumn{3}{|l|}{ What do you think about competition and initiative? } \\
\hline Outside the world of sport & -0.075 & 0.123 \\
\hline Wit & 0.162 & -0.019 \\
\hline Peopl & 0.108 & -0.003 \\
\hline Progress is only good if it benefits everybody & -0.002 & 0.104 \\
\hline \multicolumn{3}{|l|}{ Attitudes towards other cultures } \\
\hline \multicolumn{3}{|l|}{ How do you see the world around you? } \\
\hline You would like to move to another count & 0.044 & -0.006 \\
\hline You & 0.014 & 0.072 \\
\hline ural background to yo & 0.085 & -0.011 \\
\hline The person you marry must share your religion & 0.078 & 0.015 \\
\hline \multicolumn{3}{|l|}{ Attitudes towards helping other people } \\
\hline \multicolumn{3}{|l|}{ What is your view of responsibility for your own and others' lives? } \\
\hline $\begin{array}{l}\text { When people run into problems, it is usually their own fault. They have to } \\
\text { deal with it themselves }\end{array}$ & 0.127 & -0.097 \\
\hline The best way to achieve social security for ordinary people is to stand together & -0.018 & 0.231 \\
\hline $\begin{array}{l}\text { If a friend or someone in your family runs into serious problems, you will be } \\
\text { there for them - regardless that person's actions }\end{array}$ & 0.001 & 0.113 \\
\hline Society always shares the responsibility for solving people's problems & -0.033 & 0.169 \\
\hline \multicolumn{3}{|l|}{ Attitudes towards getting an education } \\
\hline An education is a good long-term investment & 0.068 & 0.032 \\
\hline Your chances of finding work increase if you take an & 0.061 & 0.058 \\
\hline If you take a long education, you risk amassing a huge student loan & 0.000 & 0.061 \\
\hline
\end{tabular}

